\title{
Conceptual Model to Assess Water Use Associated with the Life Cycle of Unconventional Oil and Gas Development
}

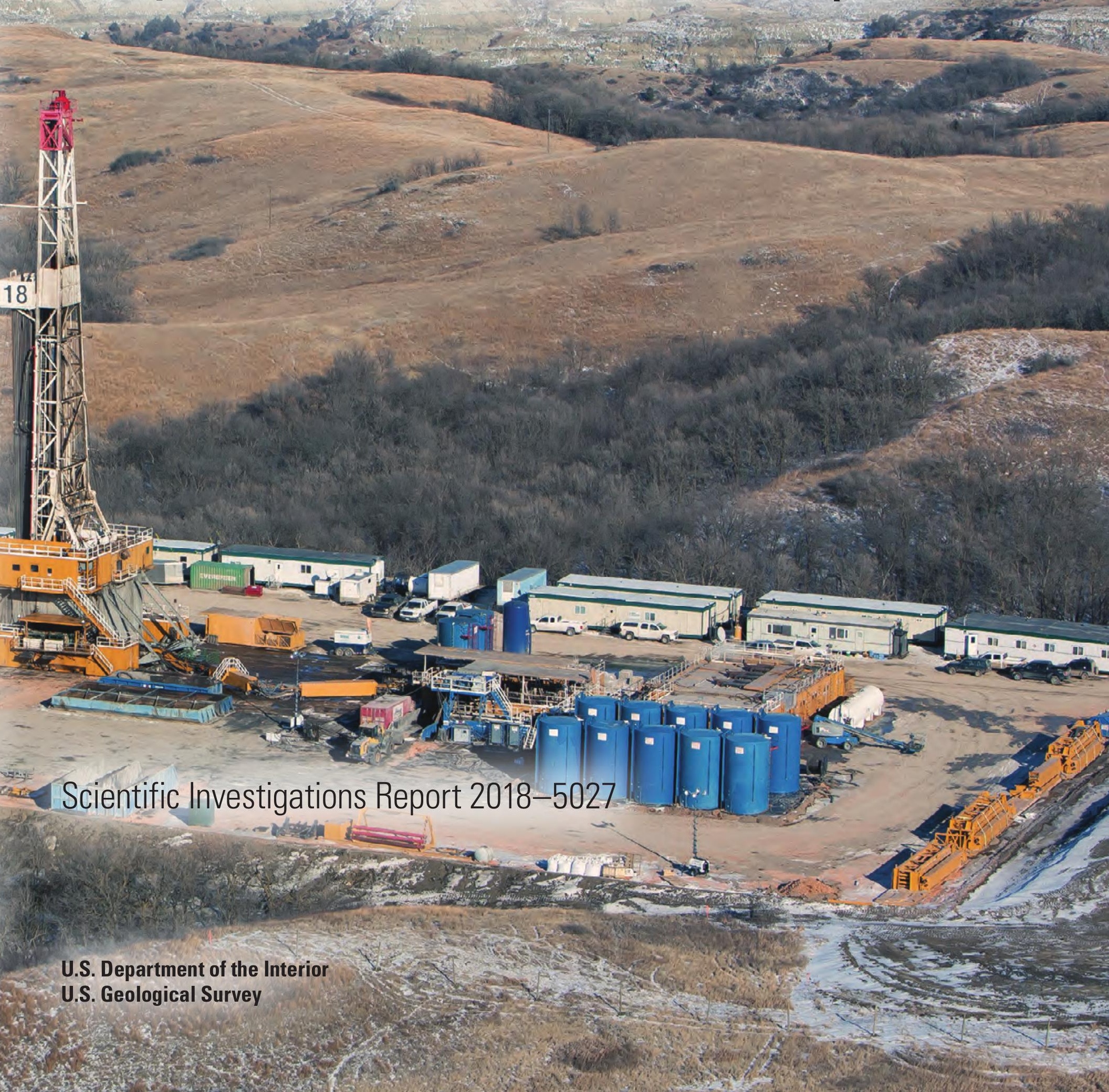


Cover. Photograph of an unconventional oil and gas development site near Lake Sakakawea in North Dakota. Photograph by Whitten Photography, used with permission. 


\section{Conceptual Model to Assess Water Use Associated with the Life Cycle of Unconventional Oil and Gas Development}

By Joshua F. Valder, Ryan R. McShane, Theodore B. Barnhart, Roy Sando, Janet M. Carter, and Robert F. Lundgren

U.S. Geological Survey Water Availability and Use Science Program

Scientific Investigations Report 2018-5027 


\title{
U.S. Department of the Interior \\ RYAN K. ZINKE, Secretary
}

\section{U.S. Geological Survey William H. Werkheiser, Deputy Director exercising the authority of the Director}

\author{
U.S. Geological Survey, Reston, Virginia: 2018
}

For more information on the USGS - the Federal source for science about the Earth, its natural and living resources, natural hazards, and the environment-visit https://www.usgs.gov or call 1-888-ASK-USGS.

For an overview of USGS information products, including maps, imagery, and publications, visit https://store.usgs.gov.

Any use of trade, firm, or product names is for descriptive purposes only and does not imply endorsement by the U.S. Government.

Although this information product, for the most part, is in the public domain, it also may contain copyrighted materials as noted in the text. Permission to reproduce copyrighted items must be secured from the copyright owner.

Suggested citation:

Valder, J.F., McShane, R.R., Barnhart, T.B., Sando, R., Carter, J.M., and Lundgren, R.F., 2018, Conceptual model to assess water use associated with the life cycle of unconventional oil and gas development: U.S. Geological Survey Scientific Investigations Report 2018-5027, 22 p., https://doi.org/10.3133/sir20185027.

ISSN 2328-0328 (online) 


\section{Contents}

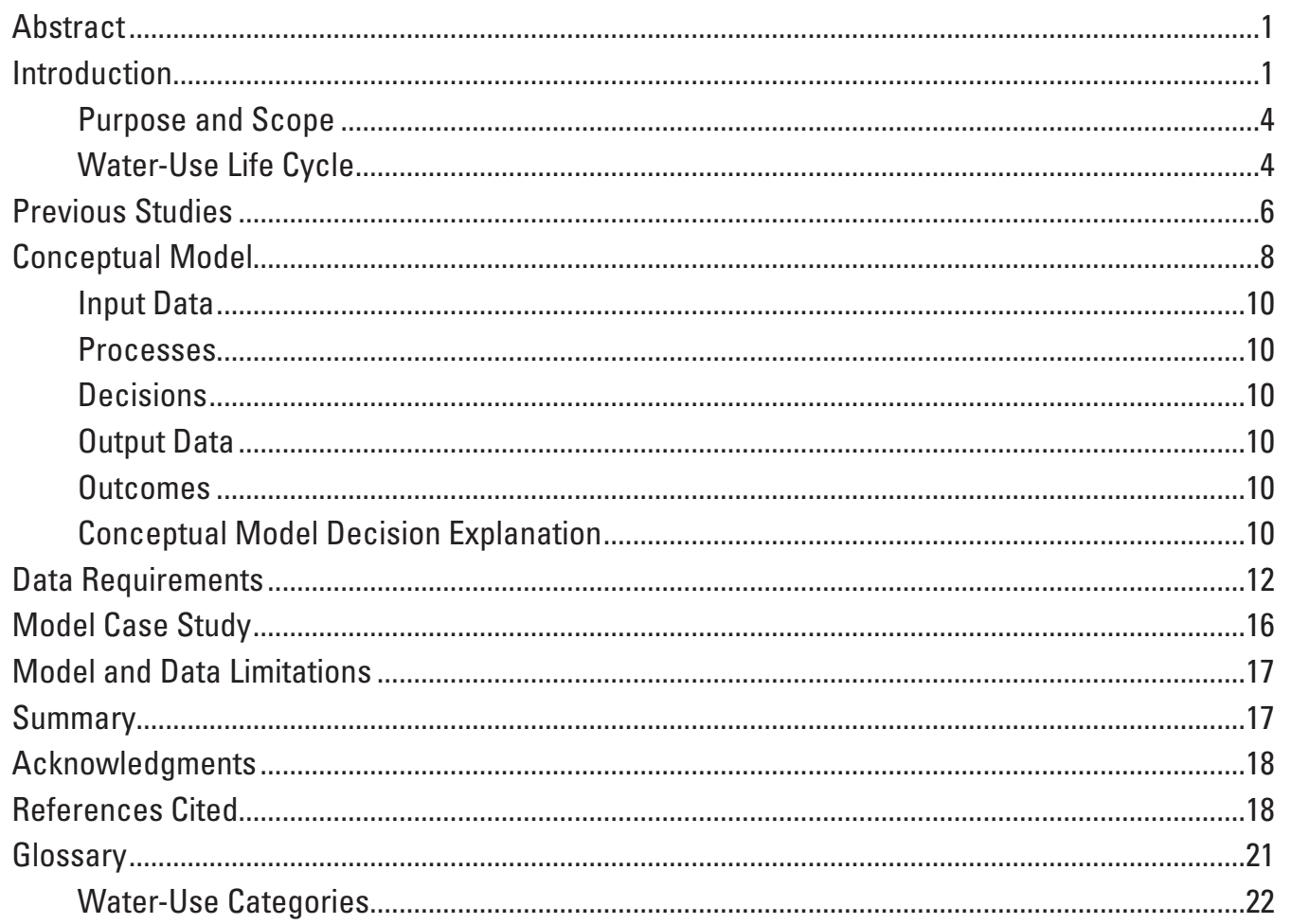




\section{Figures}

1. Schematic representation of the various water-use and energy-development components in an area of conventional and unconventional oil and gas development of the Williston Basin, highlighting the Bakken and Three Forks Formations

2. Map showing current (2016) and prospective shale plays in the conterminous United States.

3. Diagram showing direct, indirect, and ancillary water uses associated with the life cycle of unconventional oil and gas development

4. Map showing boundaries of the Williston Basin Province, Bakken total petroleum system, and Three Forks assessment units within the United States .6

5. Diagram showing conceptual model for assessing direct, indirect, and ancillary water use in an unconventional oil and gas play.

6. Subset of conceptual model flow diagram pertaining to decision 1 for assessing direct, indirect, and ancillary water use in an unconventional oil and gas play

7. Subset of conceptual model flow diagram pertaining to decision 2 for assessing direct, indirect, and ancillary water use in an unconventional oil and gas play

8. Subset of conceptual model flow diagram pertaining to decisions 3 and 4 for assessing direct, indirect, and ancillary water use in an unconventional oil and gas play.

9. Subset of conceptual model flow diagram pertaining to decision 5 for assessing direct, indirect, and ancillary water use in an unconventional oil and gas play 15

\section{Tables}

1. References for studies that investigated direct, indirect, or ancillary water uses associated with unconventional oil and gas development in seven plays in the United States

2. Hydraulic fracturing volumes of treatment water for seven unconventional oil and gas plays in the United States 


\section{Conversion Factors}

U.S. customary units to International System of Units

\begin{tabular}{lcl}
\hline Multiply & By & To obtain \\
\hline & Area & \\
\hline square mile $\left(\mathrm{mi}^{2}\right)$ & 2.590 & square kilometer $\left(\mathrm{km}^{2}\right)$ \\
\hline $\begin{array}{l}\text { barrel (bbl; petroleum, 1 bar- } \\
\text { rel=42 gal) }\end{array}$ & Volume & \\
million gallons (Mgal) & 0.1590 & cubic meter $\left(\mathrm{m}^{3}\right)$ \\
\hline
\end{tabular}

\section{Datum}

Vertical coordinate information is referenced to North American Vertical Datum of 1988 (NAVD 88).

Horizontal coordinate information is referenced North American Datum of 1983 (NAD 83).

Elevation, as used in this report, refers to distance above the vertical datum.

\section{Supplemental Information}

Italicized terms are defined in the "Glossary" section of this report.

\section{Abbreviations}

UOG unconventional oil and gas

USGS U.S. Geological Survey

WAUSP Water Availability and Use Science Program 



\title{
Conceptual Model to Assess Water Use Associated with the Life Cycle of Unconventional Oil and Gas Development
}

\author{
By Joshua F. Valder, Ryan R. McShane, Theodore B. Barnhart, Roy Sando, Janet M. Carter, and \\ Robert F. Lundgren
}

\section{Abstract}

As the demand for energy increases in the United States, so does the demand for water used to produce many forms of that energy. Technological advances, limited access to conventional oil and gas accumulations, and the rise of oil and gas prices resulted in increased development of unconventional oil and gas (UOG) accumulations. Unconventional oil and gas is developed using a method that combines directional drilling and hydraulic fracturing techniques, allowing for greater oil and gas production from previously unrecoverable reservoirs. Quantification of the water resources required for UOG development and production is difficult because of disparate data sources, variable reporting requirements across boundaries (local, State, and national), and incomplete or proprietary datasets.

A topical study was started in 2015 under the U.S. Geological Survey's Water Availability and Use Science Program, as part of the directive in the Secure Water Act for the U.S. Geological Survey to conduct a National Water Census, to better understand the relation between production of UOG resources for energy and the amount of water needed to produce and sustain this type of energy development in the United States. The Water Availability and Use Science Program goal for this topical study is to develop and apply a statistical model to better estimate the water use associated with UOG development, regardless of the location and target geologic formation. As a first step, a conceptual model has been developed to characterize the life cycle of water use in areas of UOG development.

Categories of water use and the way water-use data are collected might change over time; therefore, a generic approach was used in developing the conceptual model to allow for greater flexibility in adapting to future changes or newly available data. UOG development can be summarized into four stages: predrilling construction, drilling, hydraulic fracturing, and ongoing production. The water used in UOG production can be categorized further as direct, indirect, or ancillary water use. Direct water use is defined as the water used for drilling and hydraulic fracturing a well and for maintaining the well during ongoing production. Indirect water use is defined as the water used at or near a well pad. The water used for dust abatement also is considered an indirect use but may be applied away from the well pad. Ancillary water use is defined as the additional local or regional water use resulting from a change (for example, population) directly related to UOG development throughout the life cycle that is not used directly in the well or indirectly for any other purpose at the well pad.

The conceptual model presented in this report consists of five elements: (1) input data, (2) processes, (3) decisions, (4) output data, and (5) outcomes. The input data requirements for estimating water use associated with UOG development are somewhat onerous, and obtaining suitable datasets can be challenging because local, State, and Federal agencies do not collect data similarly. The quality of a water-use assessment that uses the conceptual model presented in this report is dependent on the quality and quantity of data that are available for a UOG play. The conceptual model can be used for an assessment with sparse data; however, having sparse data likely will result in greater uncertainty in the water-use estimates.

The conceptual model presented in this report is designed to be robust to characterize and simulate the data processing to estimate water use associated with UOG development. Although the results of an analysis that includes missing data have greater uncertainty, the analysis still can be insightful because it can establish a baseline estimate of UOG water use that may be refined further as more data become available. Analysis of models that include missing data also could aid in identifying the data most needed for future water-use estimates. Characterizing individual model limitations is important because the conceptual model can be used in future water-use studies to facilitate data compiling, data processing, estimating, and assessing UOG activities regardless of location.

\section{Introduction}

As the demand for energy increases in the United States, so does the demand for water used to produce many forms of that energy. Water and energy are essential to human existence and are linked intrinsically (Healy and others, 2015). Water cannot be delivered to homes, businesses, and industries without energy, and most forms of energy development require large 
amounts of water. The United States faces two important and sometimes competing challenges: (1) to provide sustainable supplies of freshwater for humans and ecosystems, and (2) to ensure adequate sources of energy for future generations (Healy and others, 2015). Water is associated with all steps of energy development, including fuel extraction and processing, electricity generation, and final end use (Healy and others, 2015).

Technological advances, limited access to conventional oil and gas accumulations, and the rise of oil and gas prices resulted in increased unconventional oil and gas (UOG) development. Conventional oil and gas accumulations have discrete deposits with well-defined hydrocarbon-water contacts (where the hydrocarbons are buoyant on a column of water), generally high matrix permeabilities, apparent seals and traps (fig. 1), and high recovery factors (U.S. Geological Survey, 2017). Because of the ease of extraction, conventional oil and gas extraction historically has been the most cost effective to develop through the use of primarily vertical wells, and it requires less water compared to UOG resource extraction.
Development of UOG is achieved using a method that combines directional drilling and hydraulic fracturing techniques (fig. 1) and allows for greater oil and gas production from previously unrecoverable reservoirs. The UOG resources in the United States that are developed using this method expose a larger amount of reservoir from thin horizontal units to the well bore compared to vertical wells (Carter and others, 2016). Hydraulic fracturing techniques use water and proppant (often sand) under pressure to generate and hold open fractures in the rock containing the reservoir. The process of hydraulic fracturing requires large volumes of water (Jiang and others, 2014). Quantification of the water resources required for UOG development and production is difficult because of disparate data sources, variable reporting requirements across boundaries (local, State, and national), and incomplete or proprietary datasets. These challenges necessitate a robust methodology for estimating a variety of UOG-related water-use categories that can be applicable to multiple oil and gas plays in the United States (fig. 2).

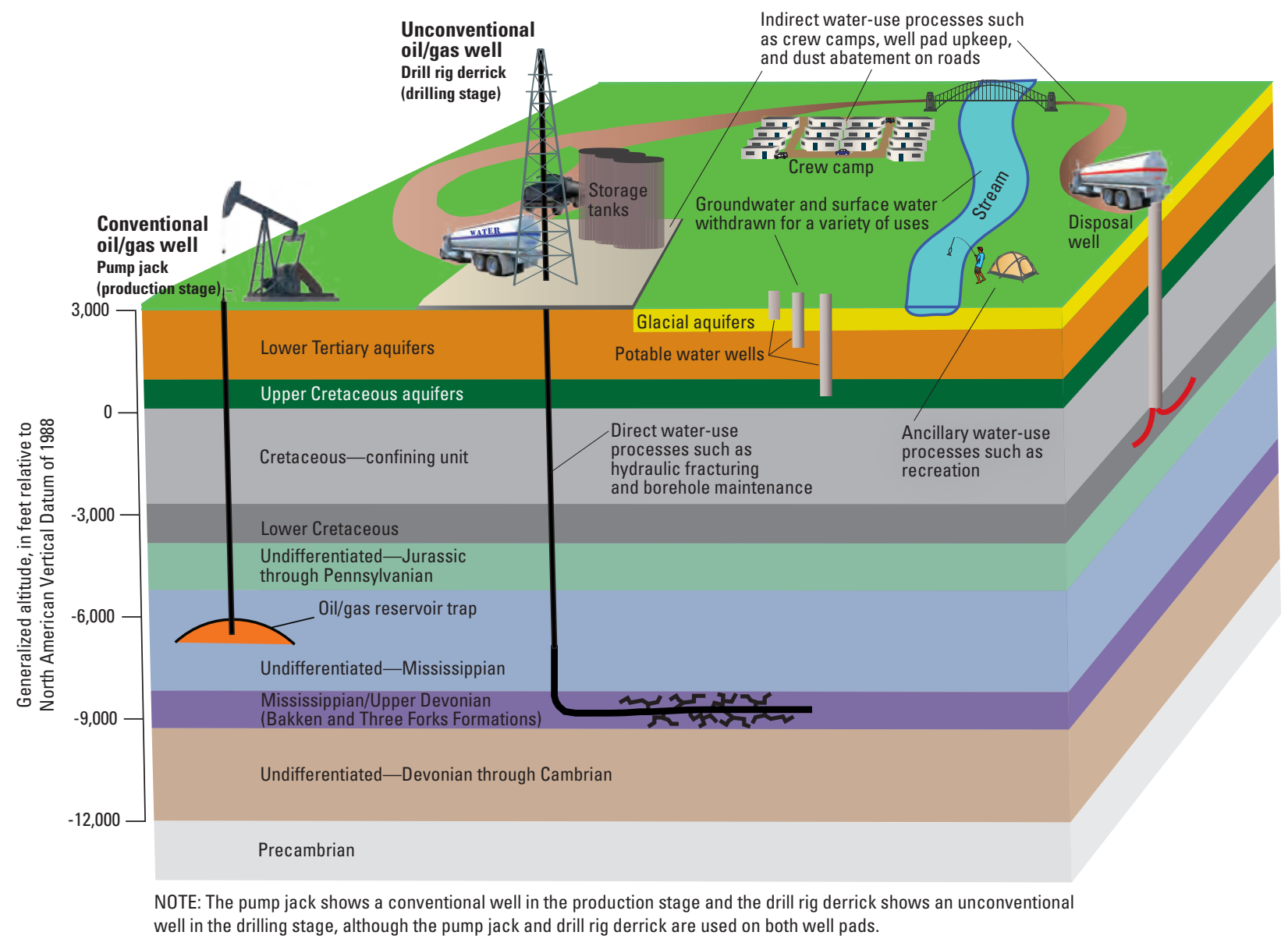

Figure 1. Schematic representation of the various water-use and energy-development components in an area of conventional and unconventional oil and gas development of the Williston Basin, highlighting the Bakken and Three Forks Formations (modified from Carter and others, 2016; Caldwell and others, 2015). 


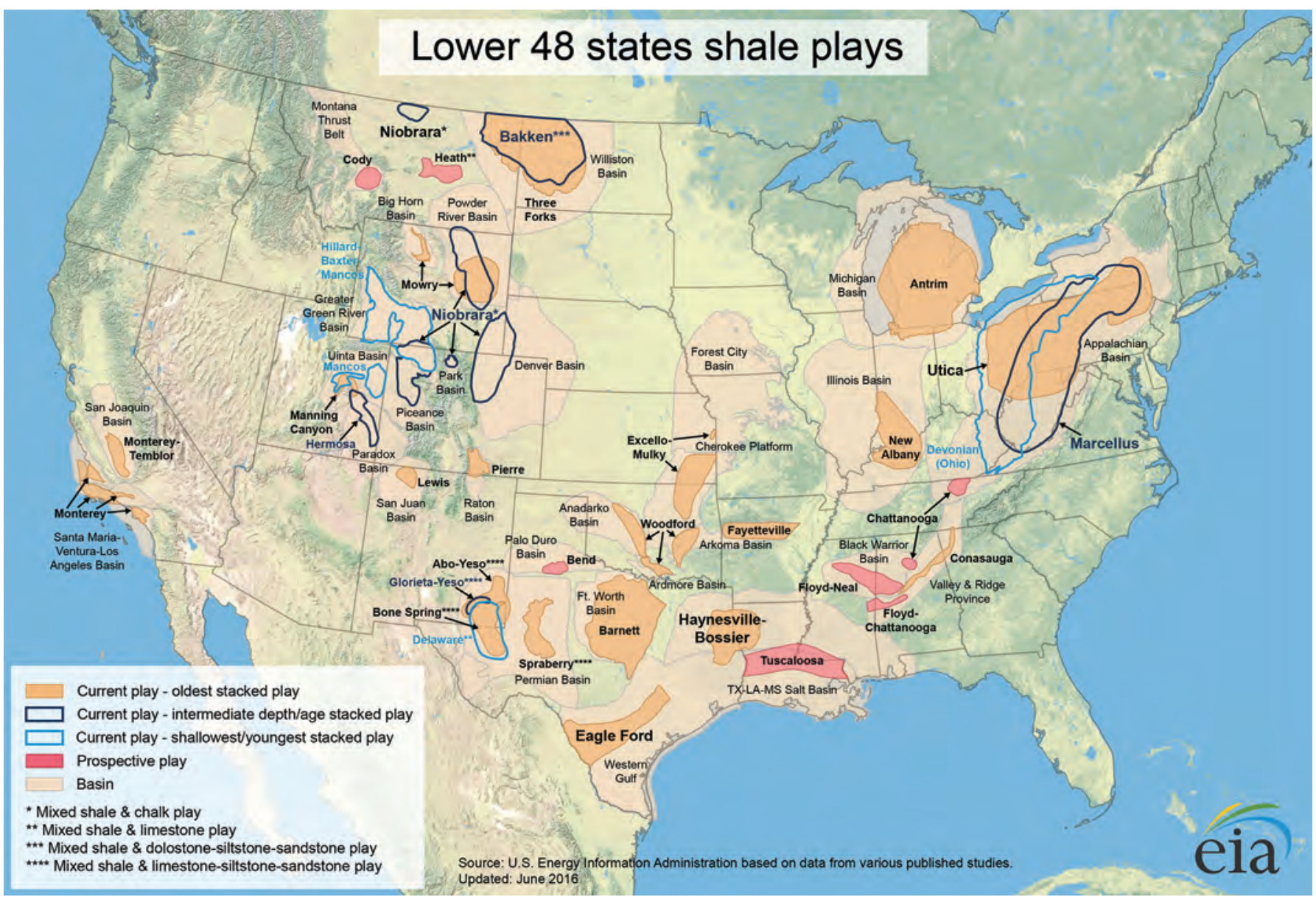

Figure 2. Current (2016) and prospective shale plays in the conterminous United States (from U.S. Energy Information Administration, 2016).

A topical study was started in 2015 under the U.S. Geological Survey's (USGS) Water Availability and Use Science Program (WAUSP), as part of the directive in the Secure Water Act for USGS to conduct a National Water Census, to better understand the relation between production of UOG resources for energy and the amount of water needed to produce and sustain this type of energy development in the United States. This relation applies to the water-use life cycle of renewable energy and nonrenewable energy as forms of UOG energy and includes extraction, production, refinement, delivery, and disposal of waste byproducts. Water-use data and models derived from this topical study can be applied to other UOG plays within the United States to help resource managers assess and account for water needs and assist in planning for future water-use needs (Carter and others, 2016). Additionally, the results from this topical study will be used to further refine the methods used in compiling water-use data for 8 of the 11 water-use categories (for example, mining, domestic selfsupplied, and public supply) in the USGS's 5-year national water-use estimates reports (https://water.usgs.gov/watuse/).

This topical study will support one of the primary goals of the WAUSP, which is to provide a more accurate assessment of the status of the water resources of the United States and assist in the determination of the quantity and quality of water that is available for beneficial uses. These assessments would identify long-term trends or changes in water availability since the 1950s in the United States and help to develop the basis for an improved ability to forecast water availability for future water needs. The National Water Census (https:// water.usgs.gov/watercensus/), a research program called for by the Secure Water Act and implemented through the WAUSP, supports studies to develop new water accounting tools and to assess water availability at regional and national scales. Studies supported by this program will target focus areas with identified water availability concerns and topical science themes related to the use of water within a specific type of environmental setting (Carter and others, 2016). Characterizing water use associated with UOG development can be difficult because water sources and uses may change based on the geologic formation and the location within the United States. The WAUSP goal for this topical study is to develop and apply a statistical model to better estimate the water use associated with UOG development, regardless of the location and target geologic formation. As a first step, a conceptual model has been developed to characterize the life cycle of water use in areas of UOG development. The conceptual model is defined 
Conceptual Model to Assess Water Use Associated with the Life Cycle of Unconventional Oil and Gas Development

in this report as the systematic approach used to standardize a method in developing a comprehensive understanding of the total water use in areas of UOG development.

Water used directly for conventional oil and gas and UOG development and production constitutes part of the estimates of water use for the mining water-use category reported in the United States (Maupin and others, 2014); however, there are many ways in which UOG development may affect water use. The conceptual model for assessing UOG water use focuses on estimating direct, indirect, and ancillary water uses associated with UOG development, of which indirect and ancillary water uses have been determined to be potentially a substantial part of the total water use associated with UOG development (Horner and others, 2016); however, more investigations into the volumes of indirect and ancillary water use are needed. The conceptual model developed is intended to facilitate the process of estimating the volume of indirect and ancillary water use associated with UOG development, which will continue to pose challenges because each State regulates the water-use reporting requirements in UOG plays, and plays can extend across State and international borders.

\section{Purpose and Scope}

The purpose of this report is to present and describe a conceptual model that will be used to estimate water use associated with UOG development and production. This model is one component of a USGS National Water Census wateruse topical study that was developed to better understand the relation between production of UOG resources for energy and the water needed to produce and sustain this type of energy development in the United States. This report defines direct, indirect, and ancillary water-use categories related to UOG development; presents a conceptual model that can be used in other UOG plays in the Nation to estimate total or partial water use associated with UOG development; characterizes the types of input data and information needed to quantify water use associated with UOG development; presents a case study that applies the conceptual model to a pilot area; and describes the limitations of the model and data.

This effort to conceptualize an approach in assessing water use associated with UOG development is intended to complement other water-use prioritization efforts and other programs with different objectives. The conceptual model presented herein was completed in 2017-18 with the information and resources available at that time. This report does not address the results of using the conceptual model, rather, the intention is to document a strategy for assessing water use in areas of UOG development. A generic approach was used to develop the conceptual model because technological advances in the UOG industry would make a more specific approach likely obsolete. Also, categories of water use and the way water-use data are collected might change over time and a generic approach will allow for greater flexibility in adapting to future changes or newly available data. The conceptual model presented in this report can be adapted and applied to future UOG water-use studies in an effort to categorize the water-use components into the WAUSP categories.

\section{Water-Use Life Cycle}

The life cycle of UOG development can be summarized into four stages: predrilling construction, drilling, hydraulic fracturing, and ongoing production (fig. 3). Water is an essential component in UOG development and is used for many purposes throughout the energy-development process. The water used in UOG production can be categorized further as direct, indirect, or ancillary water use. Direct water use is defined as the water used for drilling and hydraulic fracturing a well and for maintaining the well during ongoing production. Indirect water use is defined as the water used at or near a well pad. The water used for dust abatement also is considered an indirect use but may be applied away from the well pad. Ancillary water use is defined as the additional local or regional water use resulting from a change (for example, population) directly related to UOG development throughout the life cycle that is not used directly in the well or indirectly for any other purpose at the well pad. Additional explanation and examples of how the direct, indirect, and ancillary water uses are being characterized are presented in subsequent sections of this report.

Unconventional oil and gas techniques used for energy development in the United States have created additional demands on local and regional water resources. This demand for water is evident in most areas where UOG is developing, including the semiarid environment of the Williston Basin in western North Dakota, northwestern South Dakota, eastern Montana (fig. 4), and the Canadian Provinces of Saskatchewan and Manitoba (not shown in fig. 4). Of particular concern are the direct, indirect, and ancillary water uses that often depend on the same sources of freshwater and are required in large quantities to produce and maintain the energy resources from the Bakken play (figs. 2 and 3). In North Dakota, where the development in the Bakken Formation has been most intense, hydraulic fracturing processes have affected local and regional water supplies (Horner and others, 2016). Water resources currently (2017) used for UOG well drilling and development include groundwater from the lower Tertiary regional aquifers, Quaternary glacial aquifers, and surface water from the Missouri River and its tributaries. Concerns about overpumping of groundwater (mining) and water level declines have prompted resource managers to restrict withdrawals for energy production from aquifers below the lower Tertiary aquifers (Wanek, 2009; Fischer, 2013). Additionally, the demand for water within the Williston Basin has created opportunities for irrigators, tribes, and municipalities to lease or sell water allotments (Schuh, 2010). The effects of this change in water-use patterns on the hydrologic cycle have not been characterized fully; moreover, freshwater supplies potentially are affected during oil and gas extraction through spills, through mishandling of 


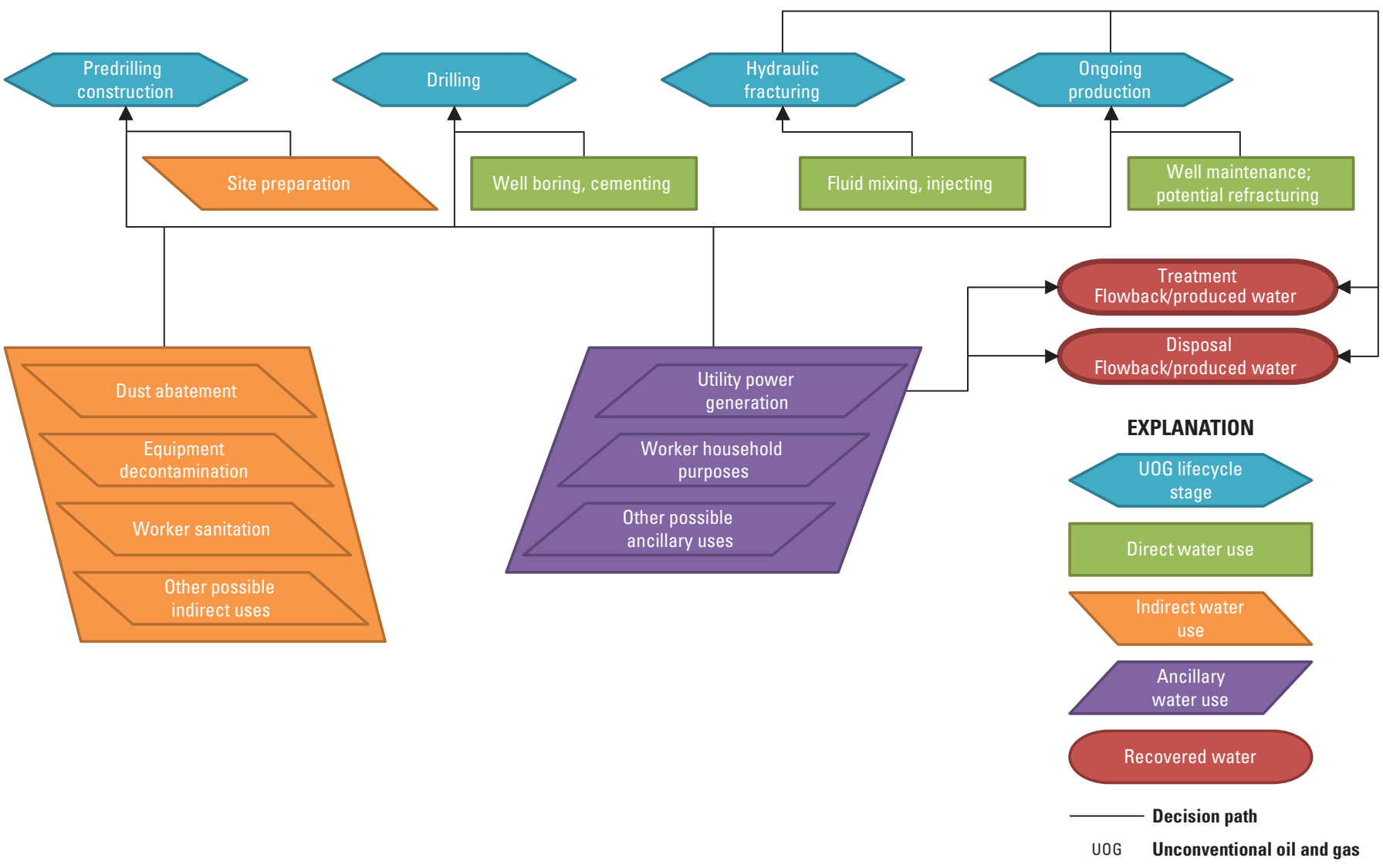

Figure 3. Direct, indirect, and ancillary water uses associated with the life cycle of unconventional oil and gas development.

produced water (brines), and from mixing with flowback water (U.S. Environmental Protection Agency, 2016). Energy development is expected to continue within the Williston Basin, with fluctuations in the number of drilling rigs expected based on incremental increases and decreases in oil prices per barrel. More than 10,000 unconventional wells were producing from the Bakken and Three Forks Formations in North Dakota in January 2018 (Helms, 2018). As such, the large-scale oil and gas development in the Williston Basin raises important questions as to the source and availability of water to meet future demand, the effects on downgradient users, and the effects on the environment.

Of the four stages in the life cycle (fig. 3), only drilling, hydraulic fracturing, and ongoing production involve direct water use. The drilling stage includes water used directly in boring the well and cementing the casing. The hydraulic fracturing stage includes water used directly for mixing the hydraulic fracturing fluid and injecting into the well. The ongoing production stage includes water used directly for maintaining the well, such as descaling the casing, and for potentially refracturing the well.

All four stages of the life cycle involve indirect water use. The indirect water uses can vary among each of the stages and may include dust abatement at the well pad during the predrilling development stage, decontamination of equipment used during the drilling and hydraulic fracturing stages, or sanitation for the workers. In addition, the predrilling and construction stage includes indirect water use for new site preparation. The initial process in preparing a new area typically includes laying concrete foundations for buildings and equipment and grading the surface of the well pad. The indirect water-use category is defined broadly within the life cycle of UOG development; therefore, depending on the location and geologic formation target of the play, additional indirect water uses that are not described in this report (fig. 3) might need to be considered.

Similar to indirect water use, ancillary water use has various purposes in all four stages of the life cycle (fig. 3). The ancillary water uses may include those by workers and by the increased populations in cities and towns that use water domestically or commercially. This increase in water demand can have a longer lasting effect on the public water supplies. In addition, utility power needed for managing the water recovered during the hydraulic fracturing and ongoing production stages (fig. 3) may use large volumes of water. Depending on the target geologic formation, water that is recovered may be treated using various processes or disposed of through injection wells or evaporation from open pits.

Power is required during each of these processes for operating machinery for processing the recovered water, for treatment of 


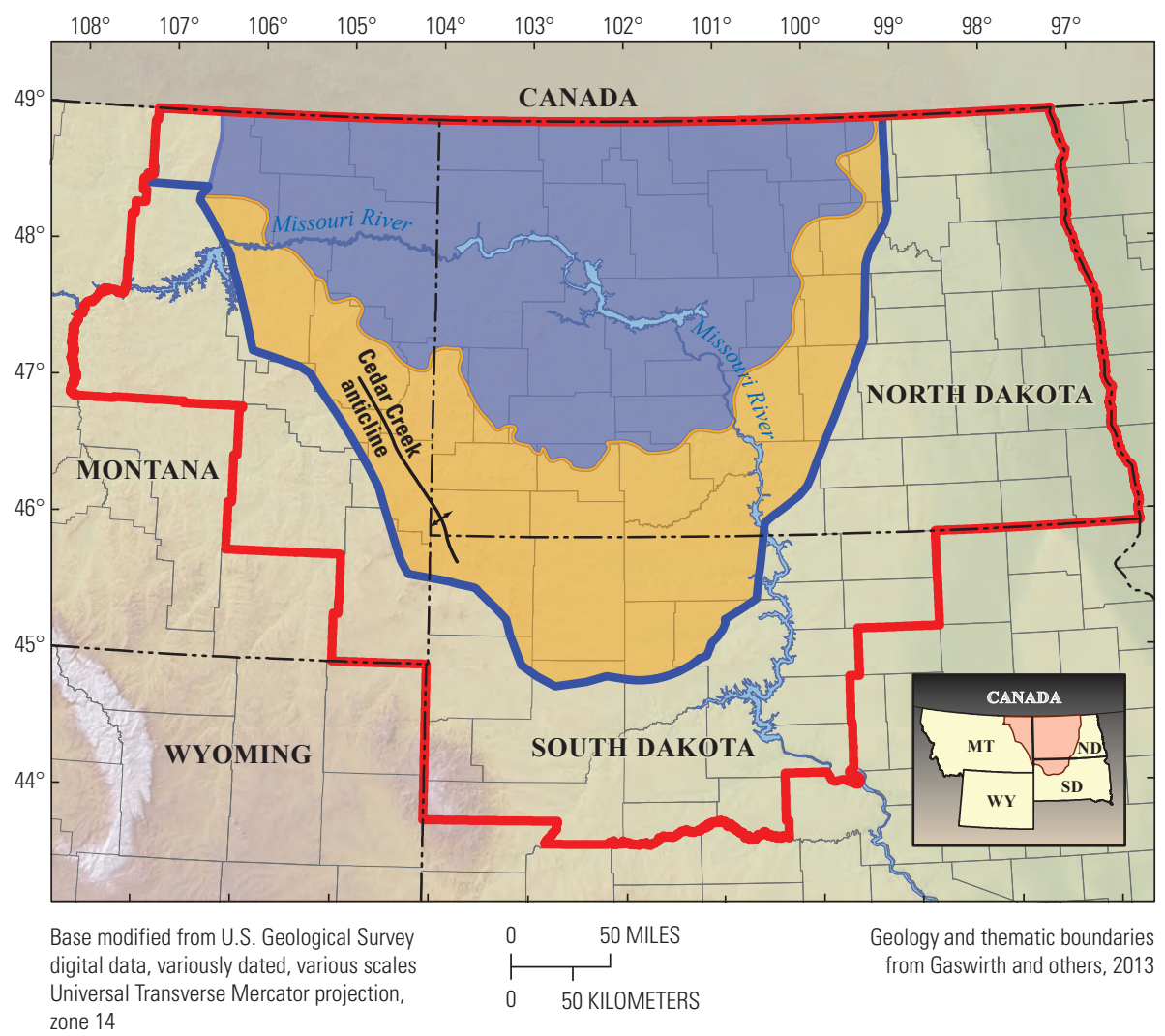

EXPLANATION

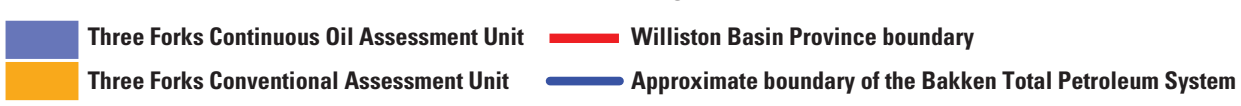

Figure 4. Boundaries of the Williston Basin Province, Bakken total petroleum system, and Three Forks assessment units within the United States (from Gaswirth and others, 2013). The Williston Basin Province is drawn on county and State borders that were completely or partially within the geologically defined Williston Basin. A total petroleum system consists of one or more assessment units, which are mappable pairs of a petroleum system in which discovered and undiscovered fields constitute a single, relatively homogeneous population (modified from Carter and others, 2016).

the recovered water, or for injecting the recovered water into a disposal well. Ancillary water use is intended to be generic in this report because other ancillary water uses than what are described in this report may need to be considered, depending on the location and target geologic formation of a play. The large number of possible ancillary uses makes characterizing ancillary uses challenging because variations in how water is being used could change from play to play and potentially have many more processes that are not described in this report.

The water needed for direct, indirect, and ancillary water use potentially can draw from any surface-water or groundwater source and can include freshwater or saline water types, fresh surface-water withdrawals being the most common source and type of water used in the UOG life cycle (U.S. Department of Energy, 2014; National Academies of Sciences, Engineering, and Medicine, 2016). Recovered water, such as flowback water or produced water that undergoes treatment (fig. 3), may be reused at a well pad; however, most of the water that is recovered (fig. 3 ) that comes from UOG development is disposed of and not reused because the quality of the water is poor (National Academies of Sciences, Engineering, and Medicine, 2016; U.S. Environmental Protection Agency, 2016).

\section{Previous Studies}

Previous studies have estimated direct, indirect, and ancillary water use associated with various components of UOG development for plays in the United States. Previous studies from seven UOG plays (tables 1 and 2) were selected for references in this report based on the availability of the data and the supporting information within those studies. These studies have been categorized according to their primary focus into direct, indirect, and ancillary water uses 
Table 1. References for studies that investigated direct, indirect, or ancillary water uses associated with unconventional oil and gas development in seven plays in the United States.

\begin{tabular}{|c|c|c|}
\hline Play (fig. 2) & Water-use category & References \\
\hline \multirow[t]{4}{*}{ Bakken } & Direct & $\begin{array}{l}\text { Chen and Carter (2016); Haines and others (2017); Lin and others (2017); Gallegos and } \\
\text { others (2015); Scanlon and others (2014); Shrestha and others (2017). }\end{array}$ \\
\hline & Indirect & Lin and others (2017). \\
\hline & Ancillary & Lin and others (2017); Horner and others (2016). \\
\hline & General/total & Freyman (2014). \\
\hline \multirow[t]{4}{*}{ Barnett } & Direct & $\begin{array}{l}\text { Clark and others (2013); Gallegos and others (2015); Nicot and others (2012); Nicot and } \\
\text { Scanlon (2012). }\end{array}$ \\
\hline & Indirect & $\left({ }^{(}\right)$. \\
\hline & Ancillary & $\left({ }^{1}\right)$. \\
\hline & General/total & Freyman (2014). \\
\hline \multirow[t]{4}{*}{ Eagle Ford } & Direct & $\begin{array}{l}\text { Kondash and Vengosh (2015); Scanlon and others (2014); Gallegos and others (2015); } \\
\text { Nicot and others (2012); Nicot and Scanlon (2012). }\end{array}$ \\
\hline & Indirect & $\left({ }^{(}\right)$. \\
\hline & Ancillary & $\left({ }^{1}\right)$. \\
\hline & General/total & Freyman (2014). \\
\hline \multirow[t]{4}{*}{ Marcellus } & Direct & Jiang and others (2014); Kargbo and others (2010); Gallegos and others (2015). \\
\hline & Indirect & Jiang and others (2014); Laurenzi and Jersey (2013). \\
\hline & Ancillary & Laurenzi and Jersey (2013). \\
\hline & General/total & Freyman (2014). \\
\hline \multirow[t]{4}{*}{ Niobrara } & Direct & Kondash and Vengosh (2015); Vengosh and others (2014); Gallegos and others (2015). \\
\hline & Indirect & $\left({ }^{(}\right)$. \\
\hline & Ancillary & $\left({ }^{1}\right)$. \\
\hline & General/total & $\left({ }^{1}\right)$. \\
\hline \multirow[t]{4}{*}{ Permian Basin } & Direct & $\begin{array}{l}\text { Kondash and Vengosh (2015); Freyman (2014); Nicot and others (2012); Gallegos and } \\
\text { others (2015). }\end{array}$ \\
\hline & Indirect & $\left({ }^{1}\right)$. \\
\hline & Ancillary & $\left({ }^{1}\right)$. \\
\hline & General/total & Freyman (2014). \\
\hline \multirow[t]{4}{*}{ Woodford } & Direct & Kondash and Vengosh (2015); Gallegos and others (2015). \\
\hline & Indirect & $\left({ }^{(}\right)$. \\
\hline & Ancillary & $\left({ }^{1}\right)$. \\
\hline & General/total & $\left({ }^{(}\right)$. \\
\hline
\end{tabular}

${ }^{1}$ No estimated volumes for this water-use component associated with the play were found through a literature search completed in 2017 as part of this report; however, it is possible that existing published data were missed. 
Table 2. Hydraulic fracturing volumes of treatment water for seven unconventional oil and gas plays in the United States.

\begin{tabular}{lcccl}
\hline \multirow{2}{*}{ Play (fig. 2) } & \multicolumn{2}{c}{ Volume of treatment water (in million gallons per well) } & \\
\cline { 2 - 4 } & Minimum & Mean & Maximum & \\
\cline { 2 - 4 } Bakken & 0.1 & 2.7 & 6.0 & Chen and Carter (2016); Haines and others (2017). \\
Barnett & 1.8 & 3.7 & 6.2 & Clark and others (2013). \\
Eagle Ford & 3.6 & 4.6 & 4.9 & Kondash and Vengosh (2015); Scanlon and others (2014). \\
Marcellus & 0.7 & 4.2 & 10.0 & Jiang and others (2014); Kargbo and others (2010). \\
Niobrara & 0.34 & 1.2 & 3.4 & Kondash and Vengosh (2015); Vengosh and others (2014). \\
Permian Basin & 0.8 & 1.0 & 1.1 & Kondash and Vengosh (2015); Freyman (2014). \\
Woodford & 2.1 & 4.2 & 6.3 & Kondash and Vengosh (2015). \\
\hline
\end{tabular}

as defined in the section "Water-Use Life Cycle." The categorized studies and their associated UOG play are listed in table 1. Water use associated with UOG development has been studied most thoroughly in the Bakken and Marcellus plays (table 1). In general, many of the previous UOG water-use studies have focused on direct water use, specifically water used in the hydraulic fracturing process because this process accounts for the largest and most immediately consumed part of UOG water use (Jiang and others, 2014). Despite the lack of studies focusing on indirect and ancillary water use, it has been determined that these two categories of water use can have substantial effects on local and regional water resources (Horner and others, 2016; Lin and others, 2017). This discrepancy highlights a need for more investigation into the volumes of indirect and ancillary water use associated with UOG development.

Direct water use includes water-use components such as drilling, hydraulic fracturing/refracturing, and ongoing production and well maintenance (fig. 3). Previous studies have estimated the water used per well for drilling and cementation (Clark and others, 2013; Scanlon and others, 2014); hydraulic fracturing (Chen and Carter, 2016; Haines, 2015; Haines and others, 2017); and well maintenance (Horner and others, 2016). Of all the UOG water-use components, hydraulic fracturing requires the most water and thus has been the focus of more studies than any other component. As such, many studies have reported estimates of the water use required for hydraulic fracturing. The water-use estimates for hydraulic fracturing from selected studies are listed in table 2, with estimates standardized to millions of gallons per well. Variability in the amount of hydraulic fracturing water used per well is large (table 2) because these estimates of treatment water can be based on a large number of wells (Haines and others, 2014; Haines and others, 2017; Scanlon and others, 2014).

Indirect water use includes water-use components such as sanitary and utility uses, washing and decontamination of equipment, and dust abatement. Indirect water use (fig. 3) is much more difficult to quantify than direct water use because it is not required to be reported in most areas of the country. In the Bakken play, indirect water use has been estimated by subtracting direct water use associated with UOG development from the total water supplied by water depots (Lin and others, 2017). Jiang and others (2014) estimated indirect water use by estimating the cost of supply chain production of fuels, electricity, and materials and used that estimate as input to the Economic Input-Output Life Cycle Assessment model (Carnegie Mellon University, 2017).

Ancillary water use includes water-use components such as water used for thermoelectric-power generation, public supply, and domestic water use by workers associated with the UOG industry. Of all the water-use categories, ancillary water use (fig. 3) has received the least amount of attention in the literature. Domestic water use by workers, who do not claim residency in the area of the State they may be working in, has been estimated in the Bakken play by multiplying annual changes in county populations during boom years by per-capita water-use estimates for associated counties (Horner and others, 2016). Despite the lack of attention ancillary water use has received in the literature, this category of water use potentially could become a substantial contributor to overall water use associated with UOG development. Horner and others (2016) determined that domestic water use by temporary workers in the Bakken play accounted for as much as 4.27 billion gallons in 2012, which is more than one-half of the total water used for hydraulic fracturing in that year.

\section{Conceptual Model}

Estimating water use associated with UOG development can be a challenge because of ongoing technological advances in developing UOG resources, variation in environmental settings among UOG plays, and economic conditions, which commonly drive UOG production. The WAUSP goal for this topical study is to develop and apply a statistical model to better estimate the water use associated with UOG development, regardless of the location and target geologic formation. A conceptual model presented in this section will be used to characterize how the statistical model will estimate the direct, indirect, and ancillary water uses associated with UOG development. The conceptual model consists of five elements: (1) input data, (2) processes, (3) decisions, (4) output data, and (5) outcomes (fig. 5). Based on the quantity or quality of the 


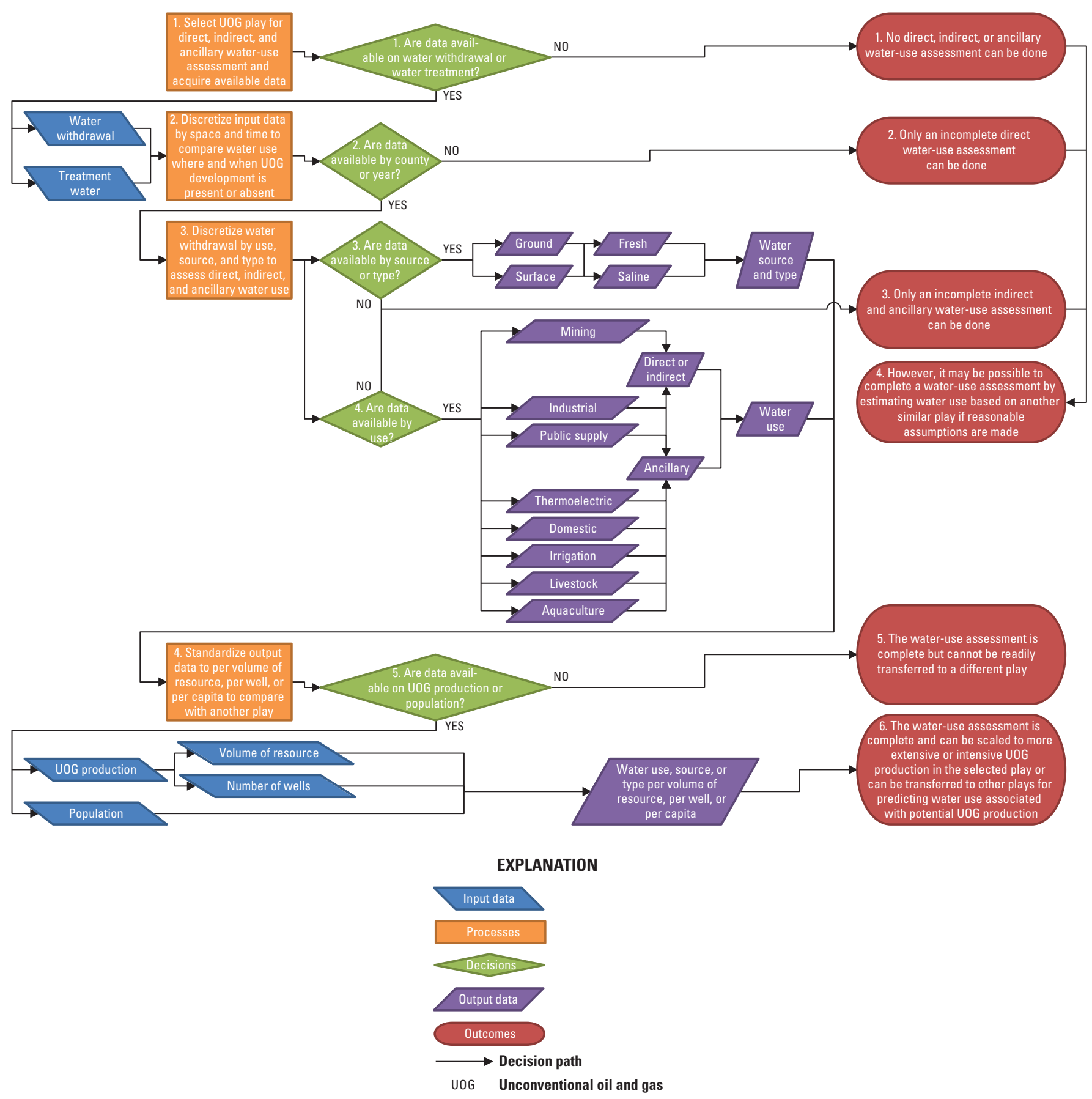

Figure 5. Conceptual model for assessing direct, indirect, and ancillary water use in an unconventional oil and gas play. 
input data that are available, processes that involve potential analysis of the input data for a UOG play can guide a "yes" or "no" decision that produces the output data and, eventually, the outcomes. The decisions can be somewhat pliable and subjective; for example, a "yes" decision may be made with a smaller quantity of input data available for a water-use assessment if the quality of the input data is acceptable. Each of the elements is described in more detail in the following subsections.

\section{Input Data}

Input data (blue parallelograms in fig. 5) are those data that are needed to make a water-use assessment possible and that will determine the completeness of the assessment. The quality and quantity of the available input data affect the ability to analyze and complete the water-use assessment. The input data are determined to be acceptable, in part, by where the UOG play is within the country and how much reporting is required by State or local agencies, the documentation and metadata of the available data, and an evaluation of the types of data that may be available to answer specific questions pertaining to a specific UOG play. States regulate the water-use reporting requirements, which alone makes the UOG assessment process challenging because plays (such as the Bakken) can extend across State and international borders. The types of data commonly collected are not reported similarly among States. The data required for an analysis are intended to be specified broadly enough in the conceptual model to capture as much information as possible regardless of the play and type of data available. The conceptual model can use all types of information, as long as the quality of the data meets the standards of the principal investigator and is representative of the UOG play. A variety of data would support the processing of this information, including (1) water withdrawal permitted by a State or local agencies, (2) volume of treatment water that goes into the well during drilling and hydraulic fracturing, (3) oil and gas production, (4) volume of water that comes out of the well (flowback or produced water), or (5) population estimated from the U.S. Census Bureau or other local demographics datasets.

\section{Processes}

Processes (orange rectangles in fig. 5) describe actions that are taken as an initial step in the conceptual model or are taken through analysis of the input data. The first process is to characterize the UOG play of interest. Other processes include discretizing the available input data and standardizing the output data for reporting. The intent of the processes is to evaluate the data availability to support the purpose and scope of the study and to adjust the study objectives to align with the UOG water-use data availability. In conjunction with the processes, key decisions, such as how to estimate direct, indirect, and ancillary water use in the selection of a UOG play of interest; are there enough data available; and what additional information may be needed, should be considered.

\section{Decisions}

Decisions (green diamonds in fig. 5) are critical components to the conceptual model because, as input data are processed through the conceptual model, decisions allow for different outcomes to be possible based on the output data that can be derived. Available input data indicating a "no" decision may lead to a water-use assessment that is relatively incomplete; if the decision is "yes," the output data that are attainable from the analysis may allow for a more complete assessment.

\section{Output Data}

Output data (purple parallelograms in fig. 5) are those water-use data associated with UOG development that can be obtained through analysis of the input data; for example, summary statistics such as average water use per year or average gallons of water use per barrel of oil or cubic foot of gas. The outcomes from a water-use assessment depend on what output data can be derived from the input data for a UOG play and what questions can be answered with the data that are available.

\section{Outcomes}

The outcomes (red ellipses in fig. 5) of the conceptual model are the results of the water-use assessment that depend on the availability of data and the data processing. Units for the water-use estimates typically would be in volume of water per volume of resource (barrel of oil or cubic foot of gas), per well, or per capita, which would offer the possibility to estimate increasing or decreasing water use as population or UOG production increases or decreases in a play. The outcomes in the conceptual model are intended to be broadly interpretable and allow for more specific conclusions based on any additional information obtained for a play of interest.

\section{Conceptual Model Decision Explanation}

The following subsection provides an explanation of how to step through all five elements of the conceptual model (fig. 5) in a general way (not specific to any UOG play). If input data on water withdrawal or treatment water are not acquired (fig. 6, decision 1: NO), then the outcome is that no quantifiable water-use assessment can be done (fig. 6 , outcome 1). If input data on water withdrawal or treatment water are acquired (fig. 6, decision 1: YES), then the next process is discretizing these input data by space and time, if possible, to compare water use within areas where, or during periods when, UOG development is present or absent (fig. 6 , 


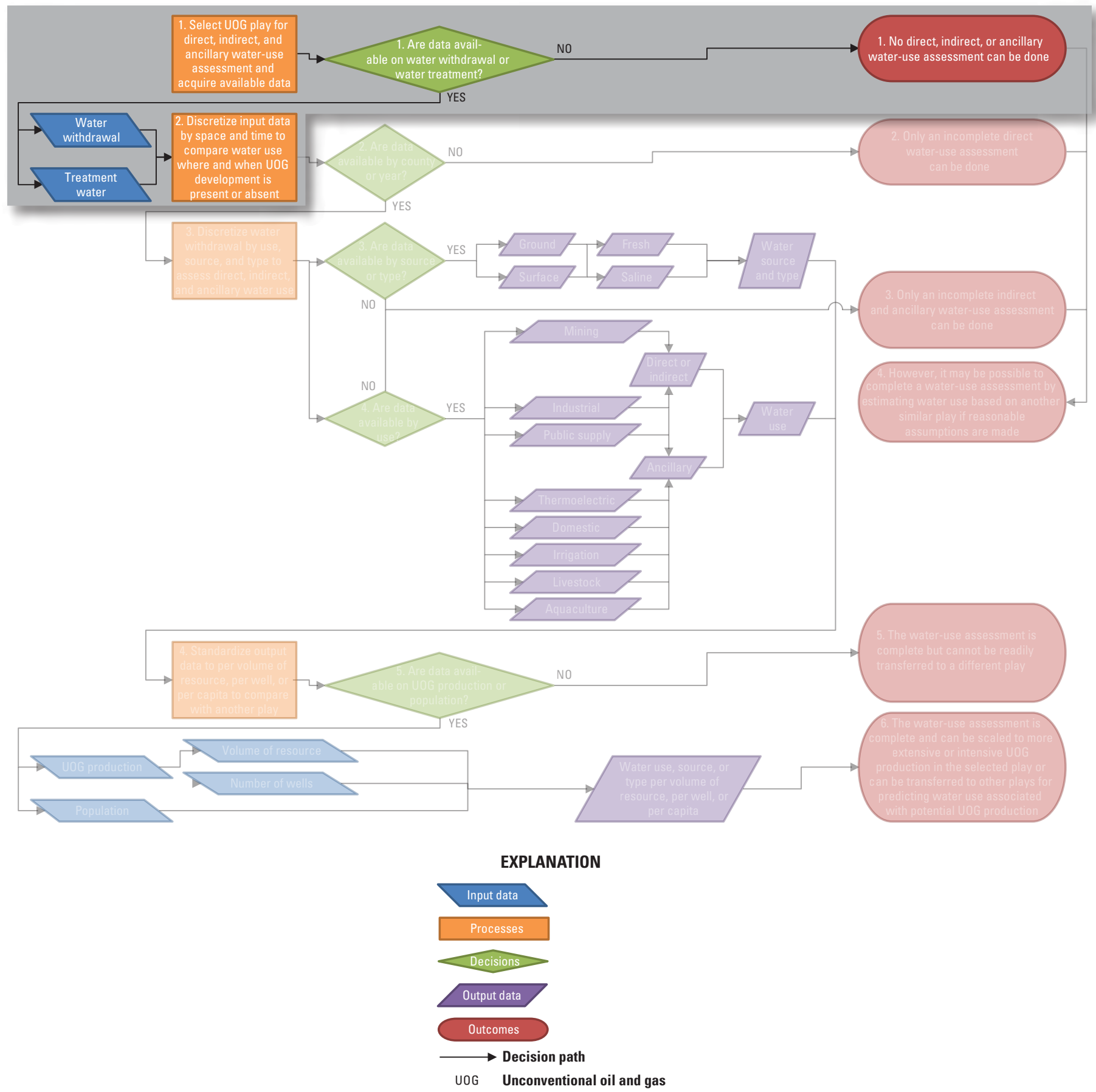

Figure 6. Subset of conceptual model flow diagram pertaining to decision 1 for assessing direct, indirect, and ancillary water use in an unconventional oil and gas play. 
process 2). If input data are spatially distributed, a comparison can be made between areas where UOG development is present and where it is absent; if input data are temporal, a comparison can be made between periods when UOG development is present and when it is absent (within the area of the play).

If input data on water withdrawal are not discretized by county or year (fig. 7, decision 2: NO), then the outcome is that only an incomplete direct water-use assessment can be done (fig. 7, outcome 2). This assessment would be considered incomplete because only some direct water uses related to drilling and hydraulic fracturing can be assessed with data on treatment water. No other direct water use, such as well maintenance, and no indirect or ancillary water use can be assessed without spatial or temporal data on water withdrawal. In addition, and importantly, if these input data are not discretized by space or time, quantitatively measuring uncertainty in the water-use estimates will be challenging. A central tendency (mean) of the estimates can be determined from these input data, but there will be limited information on dispersion (variance). If input data can be discretized by county or year (fig. 7, decision 2: YES), then the next process is discretizing these input data by water use, source, and type to assess direct, indirect, and ancillary water uses (fig. 7, process 3).

If input data on water withdrawal are not discretized by water source, type, or use (fig. 8, decision 3 or 4: NO), then the outcome would be an incomplete indirect and ancillary water-use assessment (fig. 8, outcome 3). This assessment would be considered incomplete because there is a possibility to assess all direct water uses associated with UOG development, but it will not be possible to (1) assess all indirect or ancillary water use or (2) assess the effects on water source or type associated with UOG development. A limitation of the conceptual model through this step is that no water-use assessment, or only an incomplete assessment, is possible depending on availability of data for the play (figs. 6, 7, and 8 , outcomes 1-3). Where data gaps may be an issue, it may be advisable to apply known water-use assessments and information from other plays similar to the focus area to adapt the conceptual model. Potential information for evaluating the similarity between plays includes population estimates and growth rates; hydrologic trends such as surface-water, groundwater, and water-quality trends; climate trends; the recoverable amount of UOG resources; and the typical technique for hydraulic fracturing (fig. 8, outcome 4).

If input data can be discretized by water source, type, and use (fig. 8, decisions 3 or 4: YES), then input data could be evaluated as output data as a function of direct, indirect, and ancillary water uses associated with UOG development. Standardizing the output data by UOG production and population attempts to scale the output data in the selected play, and standardizing allows the assessment to be transferred for predicting water use associated with potential UOG production in other plays (fig. 8, process 4).

If the output data are not standardized by UOG production or population (fig. 9, decision 5: NO), then the assessment is complete for direct, indirect, and ancillary water uses associated with UOG development (fig. 9, outcome 5). The output data (estimates) are total volume of water, not volume of water per volume of resource, and therefore, the estimates cannot be applied to a different play unless the potential UOG production and population of that other play are comparable. If the output data are standardized by UOG production and population (fig. 9, decision 5: YES), then the assessment is complete and could be applied to another UOG production area in the selected play or transferred to another play for predicting potential water use associated with UOG production (fig. 9, outcome 6).

\section{Data Requirements}

The input data requirements for estimating water use associated with UOG development are somewhat onerous, and obtaining suitable datasets can be challenging because local, State, and Federal agencies do not collect data similarly. This section describes the ideal datasets and challenges that may be faced when acquiring the data needed to assess the water use in UOG plays.

The quality of a water-use assessment that uses the conceptual model presented in this report is dependent on the quality and quantity of data that are available for a UOG play. A larger quantity and higher quality of data will result in a more complete assessment of direct, indirect, and ancillary water uses. The more detailed the database is with high-quality information, the more potential for comparison to other UOG plays. In addition, a larger quantity of data that is considered high quality can lead to less uncertainty in the estimates of direct, indirect, and ancillary water uses. The conceptual model has been designed such that an assessment is possible even if the ideal data requirements (large quantities of highquality data) cannot be met. The conceptual model can be used for an assessment with sparse data; however, sparse data likely will result in greater uncertainty in the water-use estimates. To reduce the uncertainty in results from an analysis, data should be acquired from as many sources as possible for a more complete assessment of direct, indirect, and ancillary water use associated with the life cycle of UOG development (fig. 5); furthermore, data quality is difficult to evaluate and is subject to interpretation by the principal investigator. The conceptual model presented in this report assumes that previously acquired datasets undergo extensive quality-assurance and quality-control reviews to determine the suitability of the data.

The optimal database for a complete assessment of water use in an area of UOG development would include the following data:

1. Total water use reported for permitted water withdrawal (for various types of uses such as public supply including deliveries, self-supply domestic and commercial, or industrial uses, to name a few), which may include data on water source, water use, and point of diversion including information about the watershed or aquifer. 


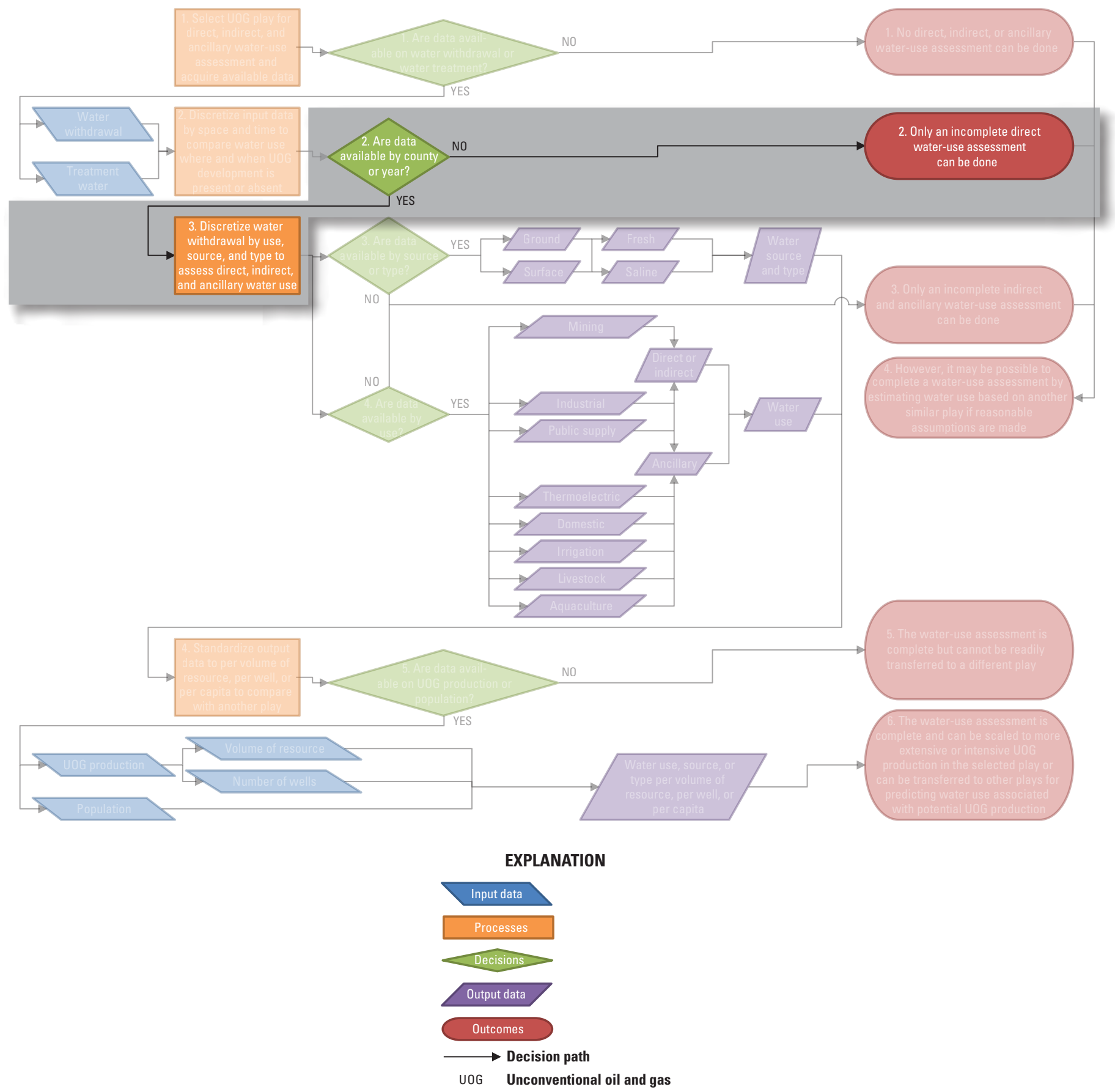

Figure 7. Subset of conceptual model flow diagram pertaining to decision 2 for assessing direct, indirect, and ancillary water use in an unconventional oil and gas play. 


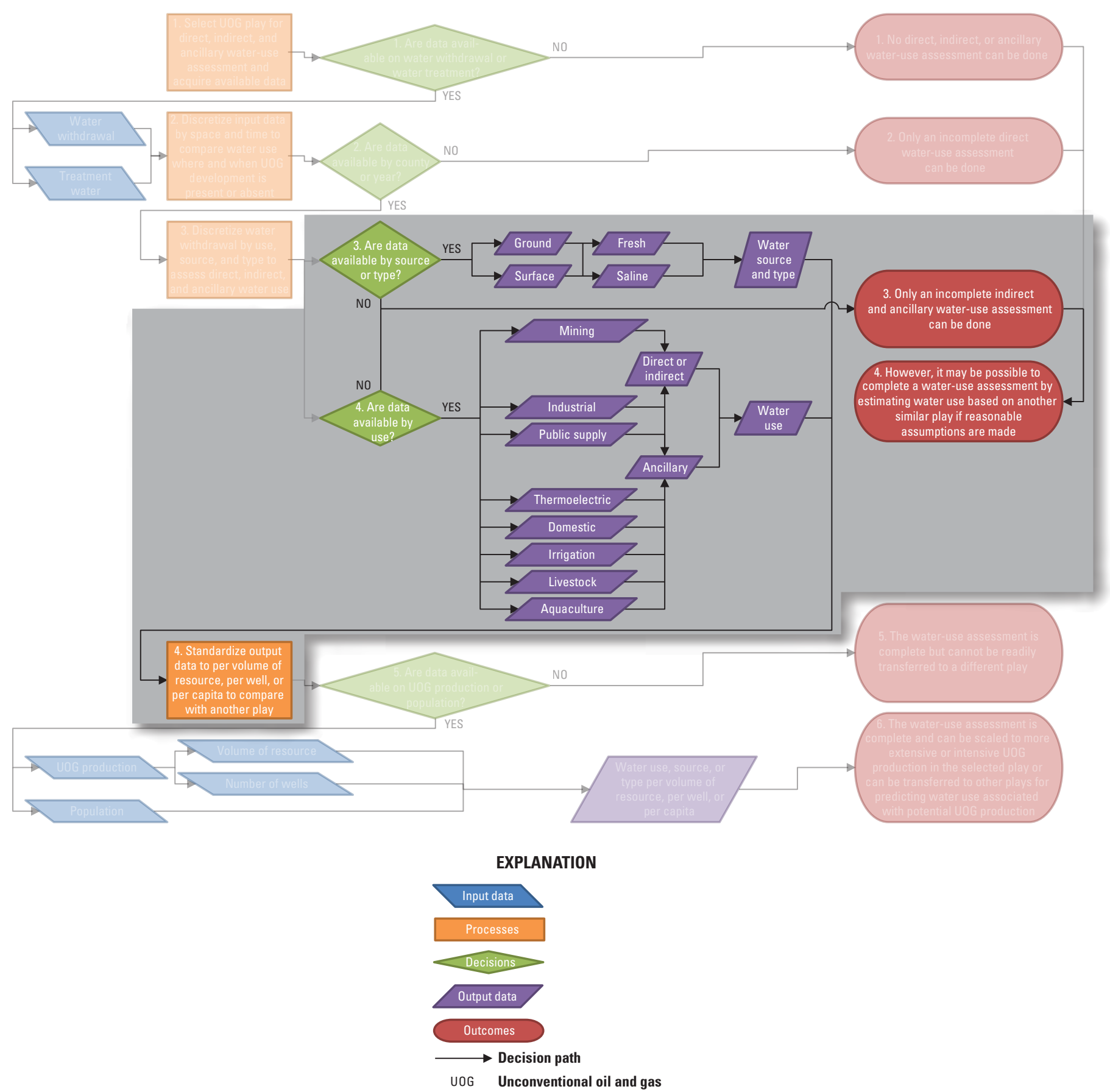

Figure 8. Subset of conceptual model flow diagram pertaining to decisions 3 and 4 for assessing direct, indirect, and ancillary water use in an unconventional oil and gas play. 


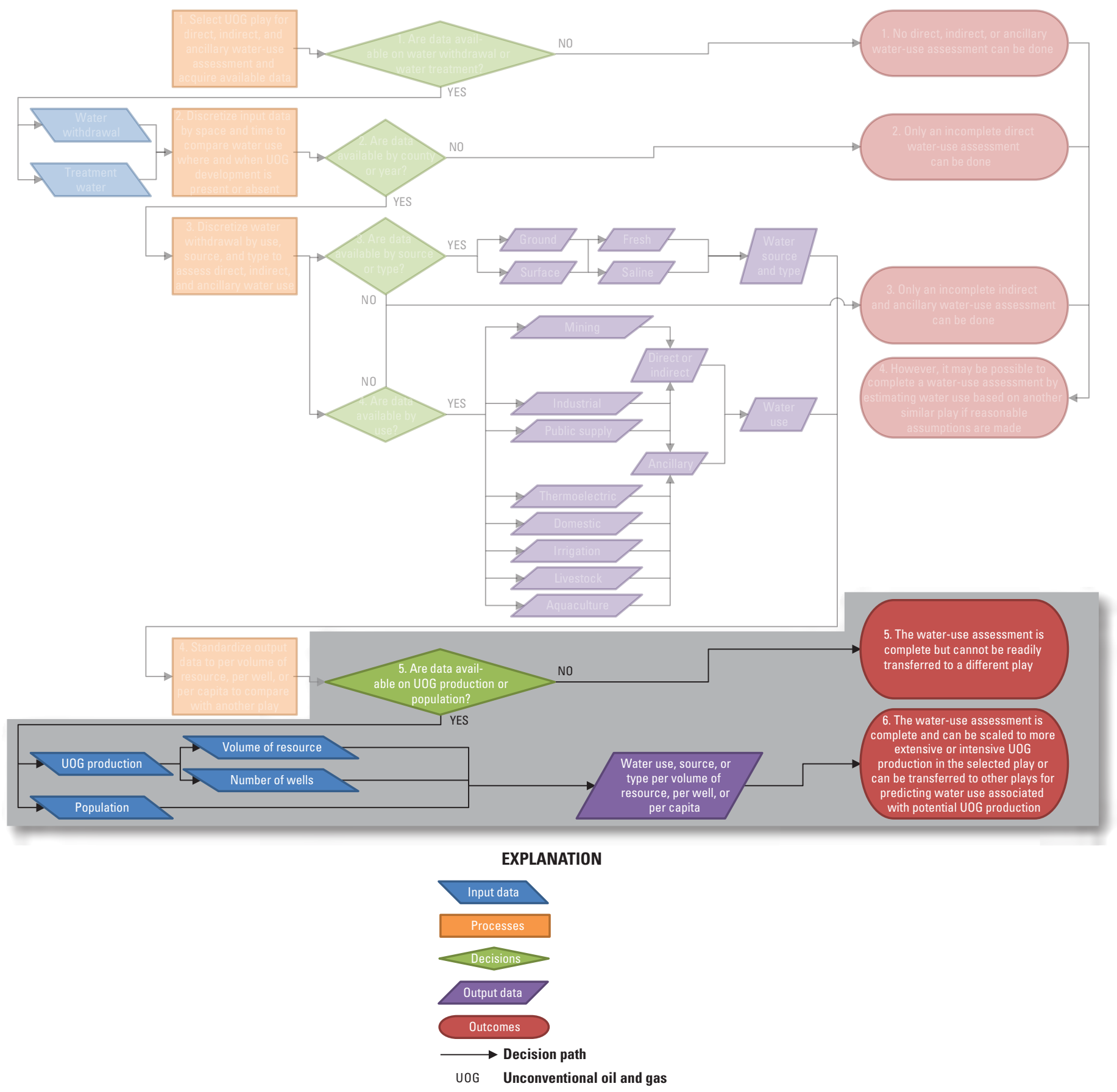

Figure 9. Subset of conceptual model flow diagram pertaining to decision 5 for assessing direct, indirect, and ancillary water use in an unconventional oil and gas play. 
2. Records from local, State, or Federal agencies that regulate the use, reuse, or discharge of treatment water used for drilling and hydraulic fracturing wells and the water that is recovered with UOG production.

3. Oil and gas production records.

Ideal datasets may be difficult to obtain because of several factors including the proprietary nature of some information and data, a lack of regulations that require reporting total water use for different purposes, a lack of information on transient laborers, and inconsistently collected data. Restrictions on available data may exist because of security reasons or simply to maintain sensitive information such as the records of well locations and well owner information or the records of oil and gas production in the IHS Markit ${ }^{\mathrm{TM}}$ well database (IHS Markit $^{\mathrm{TM}}$, 2016). This IHS Markit ${ }^{\mathrm{TM}}$ database is maintained by a for-profit corporation, and therefore, all the data are proprietary and not publicly available.

As UOG development continues to expand, there is increasing interest in maintaining databases that collect consistent data throughout the country. One such database that has been developed is the FracFocus database (FracFocus, 2017). This database was established as a chemical disclosure registry that catalogs the various chemicals used in UOG production and is managed by nongovernmental organizations. The database also maintains records of water used for hydraulic fracturing and thus will be helpful in the national assessment of water use in areas of UOG development. These records are publicly available for many UOG plays; however, data collection only began in the late 2000s. In addition, the quantity and quality of information contained in the FracFocus database is dependent on State agencies to require industry reporting to the database. If these regulations do not exist or are not enforced consistently, the database may contain data gaps.

\section{Model Case Study}

This section of the report provides a case study that specifies all five elements of the conceptual model (fig. 5) for a particular UOG play. The Williston Basin was selected as the pilot area for this topical study (Carter and others, 2016) and will be used for the case study. The Williston Basin (fig. 4) covers more than 100,000 square miles in western North Dakota, northwestern South Dakota, eastern Montana, and the Canadian Provinces of Saskatchewan and Manitoba.

Since 2005 , technological advances have rapidly expanded the production from continuous formations in the Northern Great Plains, which includes the Bakken and Three Forks Formations (fig. 1) of the Williston Basin in North Dakota, South Dakota, and Montana. The Williston Basin provides a unique opportunity to characterize water use associated with UOG development because water use in the Williston Basin was relatively stable before 2005 (Kenny and others, 2009). Because of this prior stability, any substantive change in water use since 2005 may be attributed to water-use needs to support UOG development. In addition, variability in oil and gas prices has affected production in the Williston Basin (North Dakota Department of Mineral Resources, 2016), and recent (2015) price reductions have resulted in a decrease in UOG development in the area (Helms, 2015). The fluctuation in UOG development in the Williston Basin over these 10 years (2005-15) provides an opportunity to better estimate water use with rising and falling UOG production, which will help in estimating water use in other UOG plays in the United States at various phases of development.

To demonstrate an application of the conceptual model (fig. 5), the Williston Basin was chosen as the study area and three datasets were acquired, constituting the initial step in the conceptual model (fig. 6, process 1). The three datasets included data on (1) treatment water from the IHS Markit TM database (2016), (2) annual permitted water withdrawal from the North Dakota State Water Commission (2017); and (3) annual population from the U.S. Census Bureau (2017). The data acquisition represents the next step in the conceptual model (fig. 6, decision 1: YES); however, no datasets are presented herein because the case study is a demonstration of the conceptual model to produce a potential outcome for a water-use assessment (fig. 5).

The IHS Markit ${ }^{\mathrm{TM}}$ database includes spatial and temporal information and can be discretized into annual data for the counties within the Williston Basin to correspond to the annual data by county from the North Dakota State Water Commission water permits and the U.S. Census Bureau population estimates (fig. 7, decision 2: YES). Through the evaluation of the water use, source, type (fig. 7, process 3 ), the treatment water can be categorized initially by surface water or groundwater source and freshwater or saline water type (fig. 8, decision 3: YES) and by use (fig. 8, decision 4: YES), such as industrial. The classification of hydraulic fracturing treatment water is characterized as direct water use (fig. 3 ) in areas of UOG production. Additionally, the treatment water volumes per county can be removed from the North Dakota State Water Commission water permits associated with UOG development to provide a measure of indirect water use. The North Dakota State Water Commission water permits also can be used to identify the contribution of UOG development to other water-use categories, such as the domestic and public-supply water. The effect of UOG on the domestic and public-supply water categories can be estimated by quantifying county-level population changes during periods of UOG development and production. Volumes of produced water, where available, can be used to estimate the contribution to the thermoelectric water-use category of disposal of water recovered with UOG production. These datasets are categorized as direct and indirect contribution of UOG water use to the mining wateruse category and ancillary contribution to the thermoelectric water-use category. The estimates can be used to support additional interpretations by standardizing with data on oil and gas production or population (fig. 8, process 4; fig. 9, decision 5: YES). The outcome from using the conceptual model 
for the case study includes estimates of the direct and indirect per-well contribution of UOG water use to the mining wateruse category in the Williston Basin and ancillary per-capita contribution of UOG water use to other water-use categories (fig. 9, outcome 6).

\section{Model and Data Limitations}

The conceptual model presented in this report is designed to be robust to characterize and simulate the data processing to estimate water use associated with UOG development. The conceptual model was designed with elements that can be interpreted broadly such that the data requirements for applying this model are not dependent on a particular UOG play in the United States. The conceptual model, as with any model, depends on high-quality input data to produce meaningful results. The conceptual model has been designed intentionally to allow for some interpretation of UOG water use even when datasets are not consistent or available. As highlighted in previous sections of this report, some data may not be available in certain parts of the country; for example, population information or oil and gas production data may not be available for a UOG play. A user might estimate these values based on values for similar plays around the country. The missing data also could be estimated by developing statistical relations using surrogate or correlated data. This process would require supplemental data to support the statistical relations, which would need to be validated using higher-quality data from another similar UOG play; however, as more of these estimation techniques are used to fill in data gaps, the analysis results will have greater uncertainty. In those cases, it may become necessary to represent estimates of UOG water use as ranges rather than values. Although the results of an analysis that includes missing data have greater uncertainty, the analysis can still be insightful because it can establish a baseline estimate of UOG water use that may be refined further as more data become available. Analysis of models that include missing data also could aid in identifying the data most needed for future water-use estimates. Characterizing individual model limitations is important because the conceptual model will be used in future water-use studies to facilitate data compiling, data processing, data estimating, and assessing UOG activities regardless of location.

\section{Summary}

As the demand for energy increases in the United States, so does the demand for water used to produce many forms of that energy. Technological advances, limited access to conventional oil and gas accumulations, and the rise of oil and gas prices resulted in increased development of unconventional oil and gas (UOG) accumulations. Unconventional oil and gas is developed using a method that combines directional drilling and hydraulic fracturing techniques, allowing for greater oil and gas production from previously unrecoverable reservoirs. The process of hydraulic fracturing requires large volumes of water. Quantification of the water resources required for UOG development and production is difficult because of disparate data sources, variable reporting requirements across boundaries (local, State, and national), and incomplete or proprietary datasets.

A topical study was started in 2015 under the U.S. Geological Survey's Water Availability and Use Science Program, as part of the directive in the Secure Water Act for U.S. Geological Survey to conduct a National Water Census, to better understand the relation between production of UOG resources for energy and the amount of water needed to produce and sustain this type of energy development in the United States. The Water Availability and Use Science Program goal for this topical study is to develop and apply a statistical model to better estimate the water use associated with UOG development, regardless of the location and target geologic formation. As a first step, a conceptual model has been developed to characterize the life cycle of water use in areas of UOG development.

Categories of water use and the way water-use data are collected might change over time; therefore, a generic approach was used in developing the conceptual model to allow for greater flexibility in adapting to future changes or newly available data. UOG development can be summarized into four stages: predrilling construction, drilling, hydraulic fracturing, and ongoing production. The water used in UOG production can be categorized further as direct, indirect, or ancillary water use. Direct water use is defined as the water used for drilling and hydraulic fracturing a well and for maintaining the well during ongoing production. Indirect water use is defined as the water used at or near a well pad. The water used for dust abatement also is considered an indirect use but may be applied away from the well pad. Ancillary water use is defined as the additional local or regional water use resulting from a change (for example, population) related directly to UOG development throughout the life cycle that is not used directly in the well or indirectly for any other purpose at the well pad. Of the four stages in the life cycle, only drilling, hydraulic fracturing, and ongoing production involve direct water use. All four stages of the life cycle involve indirect water use. The water needed for direct, indirect, and ancillary water use potentially can draw from any surface water or groundwater source and can include freshwater or saline water types, fresh surface-water withdrawals being the most common source and type of water used in the UOG life cycle.

The conceptual model presented in this report consists of five elements: (1) input data, (2) processes, (3) decisions, (4) output data, and (5) outcomes. Input data are those data that are needed to make a water-use assessment possible and that will determine the completeness of the assessment. Processes describe actions that are taken as an initial step in the conceptual model or are taken through analysis of the input data. Decisions are critical components to the conceptual model because, as input data are processed through the 
conceptual model, decisions allow for different outcomes to be possible based on the output data that can be derived. Output data are those water-use data associated with UOG development that can be obtained through analysis of the input data; for example, summary statistics such as average water use per year or average gallons of water per barrel of oil or cubic foot of gas. The outcomes of the conceptual model are the results of the water-use assessment that depend on the availability of data and the data processing. Units for the water-use estimates typically would be in volume of water per volume of resource (barrel of oil or cubic foot of gas), per well, or per capita, which would allow estimating increasing or decreasing water use as population or UOG production increases or decreases in a play.

The input data requirements for estimating water use associated with UOG development are somewhat onerous, and obtaining suitable datasets can be challenging because local, State, and Federal agencies do not collect data similarly. The quality of a water-use assessment that uses the conceptual model presented in this report is dependent on the quality and quantity of data that are available for a UOG play. A larger quantity and higher quality of data will result in a more complete assessment of direct, indirect, and ancillary water uses. The more comprehensive the database is with high-quality information, the more potential for comparison to other UOG plays. In addition, a larger quantity of data that is considered high quality can lead to less uncertainty in the estimates of direct, indirect, and ancillary water uses. The conceptual model can be used for an assessment with sparse data; however, sparse data likely will result in greater uncertainty in the water-use estimates. To reduce the uncertainty in results from an analysis, data should be acquired from as many sources as possible for a more complete assessment of direct, indirect, and ancillary water use associated with the life cycle of UOG development.

The conceptual model presented in this report is designed to be robust to characterize and simulate the data processing to estimate water use associated with UOG development. The conceptual model was designed with elements that can be interpreted broadly such that the data requirements for applying this model are not dependent on a particular UOG play in the United States. Although the results of an analysis that includes missing data have greater uncertainty, the analysis can still be insightful because it can establish a baseline estimate of UOG water use that may be refined further as more data become available. Analysis of models that include missing data also could aid in identifying the data most needed for future water-use estimates. Characterizing individual model limitations is important because the conceptual model will be used in future water-use studies to facilitate data compiling, data processing, data estimating, and assessing UOG activities regardless of location.

\section{Acknowledgments}

The authors thank the U.S. Geological Survey Water Availability and Use Science Program for their support of past and ongoing studies that provided valuable information for developing the conceptual model. Several personnel at the U.S. Geological Survey assisted with the collection, processing, and analysis of water-use data. Bret Bruce, Molly Maupin, Mindi Dalton, Sonya Jones, Greg Delzer, Joanna Thamke, and Kathleen Rowland provided insightful edits and comments for this report. Seth Haines provided technical guidance for processing the data on unconventional oil and gas water use and production. Finally, Skip Vecchia provided technical guidance for conceptualizing the statistical model to estimate water use.

\section{References Cited}

Caldwell, R.R., Peterman, Z.E., and Gallegos, T.J., 2015, Characterization of produced-water chemistry of the Williston Basin, Montana, North Dakota, and South Dakota through 2014 [abs]: Montana Section of American Water Resources Association annual conference, Missoula, Mont., October 7-9, 2015.

Carnegie Mellon University, 2017, Economic Input-Output Life Cycle Assessment (EIO-LCA) — Free, fast, easy life cycle assessment: Carnegie Mellon University web page, accessed December 20, 2017, at http://www.eiolca.net/.

Carter, J.M., Macek-Rowland, K.M., Thamke, J.N., and Delzer, G.C., 2016, Estimating national water use associated with unconventional oil and gas development: U.S. Geological Survey Fact Sheet 2016-3032, 6 p. [Also available at https://doi.org/10.3133/fs20163032.]

Chen, Huan, and Carter, K.E., 2016, Water usage for natural gas production through hydraulic fracturing in the United States from 2008 to 2014: Journal of Environmental Management, v. 170, no. 1, p. 152-159. [Also available at https://doi.org/10.1016/j.jenvman.2016.01.023.]

Clark, C.E., Horner, R.M., and Harto, C.B., 2013, Life cycle water consumption for shale gas and conventional natural gas supporting information: Environmental Science \& Technology, v. 47, no. 20, p. 11829-11836. [Also available at https://doi.org/10.1021/es4013855.]

Fischer, Kimberly, 2013, Groundwater flow model inversion to assess water availability in the Fox Hills-Hell Creek aquifer: North Dakota State Water Commission, North Dakota Water Resource Investigation No. 54, accessed December 20 2017, at http://www.swc.nd.gov/info_edu/reports and_publications/pdfs/wr_investigations/wr54_report.pdf. 
FracFocus, 2017, FracFocus Chemical Disclosure Registry: FracFocus web page, accessed September 2017 at https:// fracfocus.org.

Freyman, Monika, 2014, Fracturing and water stress-Water demand by the numbers-Shareholder, lender and operator guide to water sourcing: Boston, Mass., Ceres, 85 p., accessed October 5, 2017, at https://www.ceres.org/ resources/reports/hydraulic-fracturing-water-stress-waterdemand-numbers.

Gallegos, T.J., Varela, B.A., Haines, S.S., and Engle, M.A., 2015, Hydraulic fracturing water use variability in the United States and potential environmental implications: Water Resources Research, v. 51, no. 7, p. 5839-5845. [Also available at https://doi.org/10.1002/2015WR017278.]

Gaswirth, S.B., Marra, K.R., Cook, T.A., Charpentier, R.R., Gautier, D.L., Higley, D.K., Klett, T.R., Lewan, M.D., Lillis, P.G., Shenk, C.J., Tennyson, M.E., and Whidden, K.J., 2013, Assessment of undiscovered oil resources in the Bakken and Three Forks Formations, Williston Province, Montana, North Dakota, and South Dakota, 2013: U.S. Geological Survey Fact Sheet 2013-3013, 4 p., accessed December 3, 2015, at https://pubs.usgs.gov/fs/2013/3013/.

Haines, S.S., 2015, Methodology for assessing quantities of water and proppant injection, and water production associated with development of continuous petroleum accumulations: U.S. Geological Survey Open-File Report 2015-1117, 18 p. [Also available at https://doi.org/10.3133/ ofr20151117.]

Haines, S.S., Cook, T.A., Thamke, J.N., Davis, K.W., Long, A.J., Healy, R.W., Hawkins, S.J., and Engle, M.A., 2014, A framework for assessing water and proppant use and flowback water extraction associated with development of continuous petroleum resources: U.S. Geological Survey Fact Sheet 2014-3010, 6 p. [Also available at https://doi. org/10.3133/fs20143010.]

Haines, S.S., Varela, B.A., Hawkins, S.J., Gianoutsos, N.J., Thamke, J.N., Engle, M.A., Tennyson, M.E., Schenk, C.J., Gaswirth, S.B., Marra, K.R., Kinney, S.A., Mercier, T.J., and Martinez, C.D., 2017, Assessment of water and proppant quantities associated with petroleum production from the Bakken and Three Forks Formations, Williston Basin Province, Montana and North Dakota, 2016: U.S. Geological Survey Fact Sheet 2017-3044, 4 p. [Also available at https://doi.org/10.3133/fs20173044.]

Healy, R.W., Alley, W.M., Engle, M.A., McMahon, P.B., and Bales, J.D., 2015, The water-energy nexus-An earth science perspective: U.S. Geological Survey Circular 1407, 107 p. [Also available at https://doi.org/10.3133/cir1407.]
Helms, Lynn, 2015, Director's cut: North Dakota Industrial Commission, Department of Mineral Resources, accessed December 7, 2015, at https://www.dmr.nd.gov/oilgas/directorscut/directorscut-2015-11-13.pdf.

Helms, Lynn, 2018, Director's cut: North Dakota Industrial Commission, Department of Mineral Resources, accessed February 16, 2018, at https://www.dmr.nd.gov/oilgas/directorscut/directorscut-2018-01-16.pdf.

Horner, R.M., Harto, C.B., Jackson, R.B., Lowry, E.R., Brandt, A.R., Yeskoo, T.W., Murphy, D.J., and Clark, C.E., 2016, Water use and management in the Bakken Shale oil play in North Dakota: Environmental Science \& Technology, v. 50, no. 6, p. 3275-3282. [Also available at https:// doi.org/10.1021/acs.est.5b04079.]

IHS Markit ${ }^{\mathrm{TM}}$, 2016, US Well History and Production Database: Englewood, Colo., IHS Markit ${ }^{\mathrm{TM}}$, accessed August 2016 at https://www.ihsenergy.com. [Available from IHS Markit $^{\mathrm{TM}}, 15$ Inverness Way East, Englewood, CO 80112.]

Jiang, Mohan, Hendrickson, C.T., and VanBriesen, J.M., 2014, Life cycle water consumption and wastewater generation impacts of a Marcellus Shale gas well: Environmental Science \& Technology, v. 48, no. 3, p. 1911-1920. [Also available at https://doi.org/10.1021/es4047654.]

Kargbo, D.M., Wilhelm, R.G., and Campbell, D.J., 2010, Natural gas plays in the Marcellus Shale - Challenges and potential opportunities: Environmental Science \& Technology, v. 44, no. 15 , p. 5679-5684. [Also available at https:// doi.org/10.1021/es903811p.]

Kenny, J.F., Barber, N.L., Hutson, S.S., Linsey, K.S., Lovelace, J.K., and Maupin, M.A., 2009, Estimated use of water in the United States in 2005: U.S. Geological Survey Circular 1344, 52 p. [Also available at https://pubs.usgs. gov/circ/1344/.]

Kondash, Andrew, and Vengosh, Avner, 2015, Water footprint of hydraulic fracturing: Environmental Science \& Technology Letters, v. 2, no. 10, p. 276-280. [Also available at https://doi.org/10.1021/acs.estlett.5b00211.]

Laurenzi, I.J., and Jersey, G.R., 2013, Life cycle greenhouse gas emissions and freshwater consumption of Marcellus Shale gas: Environmental Science \& Technology, v. 47, no. 9, p. 4896-4903. [Also available at https://doi. org/10.1021/es305162w.]

Lin, Zhulu, Lin, Tong, Lim, S.H., Hove, M.H., and Schuh, W.M., 2017, Impacts of Bakken shale oil development on regional water uses and supply: Journal of the American Water Resources Association, v. 54, no. 1, p. 225-239. [Also available at https://doi.org/10.1111/17521688.12605.] 
Maupin, M.A., Kenny, J.F., Hutson, S.S., Lovelace, J.K., Barber, N.L., and Linsey, K.S., 2014, Estimated use of water in the United States in 2010: U.S. Geological Survey Circular 1405, 64 p. [Also available at https://doi.org/10.3133/ cir1405.]

National Academies of Sciences, Engineering, and Medicine, 2016, Flowback and produced waters - Opportunities and challenges for innovation-Proceedings of a workshop: Washington, D.C., The National Academies Press, 62 p. [Also available at https://doi.org/10.17226/24620.]

Nicot, J.P., Reedy, R.C., Costley, R.A., and Huang, Yun, 2012, Oil and gas water use in Texas-Update to the 2011 Mining Water Use Report: Prepared for Texas Oil and Gas Association, accessed November 1, 2017, at https://www. twdb.texas.gov/publications/reports/contracted_reports/ doc/0904830939_2012Update_MiningWaterUse.pdf.

Nicot, J.P., and Scanlon, B.R., 2012, Water use for shalegas production in Texas, U.S.: Environmental Science \& Technology, v. 46, no. 6, p. 3580-3586. [Also available at https://doi.org/10.1021/es204602t.]

North Dakota Department of Mineral Resources, 2016, North Dakota drilling and production statistics: North Dakota Department of Mineral Resources web page, accessed March 14, 2016, at https:/www.dmr.nd.gov/oilgas/stats/ statisticsvw.asp.

North Dakota State Water Commission, 2017, Water permits: North Dakota State Water Commission web page, accessed October 19, 2017, at http://www.swc.nd.gov/info_edu/ map_data_resources/waterpermits/.

Oil and Gas Mineral Services, 2010, Oil and gas terminology: MineralWise web page, accessed December 4, 2017, at http://www.mineralweb.com/library/oil-and-gas-terms/.

Scanlon, B.R., Reedy, R.C., and Nicot, J.P., 2014, Comparison of water use for hydraulic fracturing for unconventional oil and gas versus conventional oil: Environmental Science \& Technology, v. 48, no. 20, p. 12386-12393. [Also available at https://doi.org/10.1021/es502506v.]

Schuh, W.M., 2010, Water appropriation requirements, current water use, and water availability for energy industries in North Dakota-A 2010 summary-Response to House Bill 1322, Section 2 of the 61st Legislative Assembly of North Dakota,: North Dakota State Water Commission Water Resources Investigation No. 49, accessed February 16, 2018, at http://www.swc.nd.gov/info_edu/reports and_publications/pdfs/wr_investigations/wr49_report.pdf.
Shrestha, Namita, Chilkoor, Govinda, Wilder, Joseph, Gadhamshetty, Venkataramana, and Stone, J.J., 2017, Potential water resource impacts of hydraulic fracturing from unconventional oil production in the Bakken shale: Water Research, v. 108, no. 1, p. 1-24. [Also available at https:// doi.org/10.1016/j.watres.2016.11.006.]

U.S. Census Bureau, 2017, Population and housing unit estimates datasets: U.S. Census Bureau web page, accessed October 19, 2017, at https://www.census.gov/programssurveys/popest/data/data-sets.html.

U.S. Department of Energy, 2014, The water-energy nexus - Challenges and opportunities: U.S. Department of Energy DOE/EPSA-0002, accessed October 19, 2017, at https://energy.gov/sites/prod/files/2014/07/f17/Water\%20 Energy\%20Nexus\%20Full\%20Report\%20July\%202014. pdf.

U.S. Energy Information Administration, 2016, Shale gas and oil plays, lower 48 states (June 30, 2016): U.S. Energy Information Administration web page, accessed December 1, 2017, at https:/www.eia.gov/maps/maps.htm.

U.S. Energy Information Administration, 2017a, Glossary: U.S. Energy Information Administration web page, accessed December 4, 2017, at https:/www.eia.gov/tools/glossary/.

U.S. Energy Information Administration, 2017b, What is energy? Explained: U.S. Energy Information Administration web page, accessed February 16, 2018, at https://www.eia. gov/energyexplained/index.cfm?page=about_home.

U.S. Environmental Protection Agency, 2016, Hydraulic fracturing for oil and gas-Impacts from the hydraulic fracturing water cycle on drinking water resources in the United States: U.S. Environmental Protection Agency EPA/600/R16/236Fa, accessed December 20, 2017, at https://cfpub. epa.gov/ncea/hfstudy/recordisplay.cfm?deid $=332990$.

U.S. Geological Survey, 2017, Energy glossary and acronym list: U.S. Geological Survey, Energy Resources Program Web page: accessed November 14, 2017, at https://energy. usgs.gov/GeneralInfo/HelpfulResources/EnergyGlossary. aspx.

Vengosh, Avner, Jackson, R.B., Warner, Nathaniel, Darrah, T.H., and Kondash, Andrew, 2014, A critical review of the risks to water resources from unconventional shale gas development and hydraulic fracturing in the United States: Environmental Science \& Technology, v. 48, no. 15, p. 8334-8348. [Also available at https://doi.org/10.1021/ es405118y.]

Wanek, Alan, 2009, Recommended decision for City of Alexander Water Permit Application No. 5990: Bismarck, N. Dak., Office of the State Engineer, North Dakota State Water Commission, 141 p. 


\section{Glossary}

ancillary water use Water used in support of unconventional oil and gas development throughout the life cycle that is not used directly in the well or indirectly for any other purpose at the well pad.

conceptual model A systematic approach used to describe a complex system to gain a comprehensive understanding of the relations between various elements or components of a system.

conventional oil and gas Crude oil and natural gas that are produced by a well drilled into a geologic formation in which the reservoir and fluid characteristics permit the oil and natural gas to readily flow to the well bore (U.S. Energy Information Administration, 2017a).

direct water use Water used for drilling and hydraulic fracturing a well and for maintaining the well during ongoing production.

flowback water The term is defined multiple ways in the literature. In general, it is fluids predominantly containing hydraulic fracturing fluid that return from a well to the surface (U.S. Environmental Protection Agency, 2016).

hydraulic fracturing Method for enhancing the permeability of an oil or gas reservoir rock by applying high pressure to isolated sections of the well bore to create fractures in the rock. The process of hydraulic fracturing involves injecting fluids into a well under pressures high enough to fracture the host rock, thereby increasing the permeability of the rock and facilitating the extraction of the hydrocarbon resource (Healy and others, 2015).

indirect water use The water used at or near a well pad. The water used for dust abatement also is considered an indirect use but may be applied away from the well pad. nonrenewable energy Sources that will be completely exhausted or will not be replenished for thousands or even millions of years. Most sources of nonrenewable energy are fossil fuels. Fossil fuels were created from the remains of marine creatures decayed millions of years ago under heat and pressure. Most fossil fuels are burned to create energy and electricity (U.S. Energy Information Administration, 2017b).

plays A set of oil or gas accumulations sharing similar geologic and geographic properties, such as source rock, hydrocarbon type, and migration pathways (Oil and Gas Mineral Services, 2010).

produced water A mixture of water naturally present in the reservoir, liquids used in the drilling and development process, and possibly hydrocarbon compounds associated with natural gas or oil. The chemistry of these waters varies, but they can be many times more saline than seawater and can include inorganic salts, dispersed oil, dissolved organic compounds, radionuclides, bacteria, and solids (Healy and others, 2015).

proppant Granular material, typically sand, used to hold open fractures created during hydraulic fracturing (Haines and others, 2014).

renewable energy Energy resources that are naturally replenished but flow limited. They are virtually inexhaustible in duration but limited in the amount of energy that is available per unit of time. Renewable energy resources include biomass, hydro, geothermal, solar, wind, ocean thermal, wave action, and tidal action (U.S. Energy Information Administration, 2017a).

unconventional oil and gas develop-

ment The method used for directional drilling and hydraulic fracturing techniques (U.S. Energy Information Administration, 2017a). 


\section{Water-Use Categories}

A total of 8 of 11 water-use categories (Maupin and others, 2014) are defined in this section and shown in figure 5.

The commercial, hydroelectric-power generation, and wastewater treatment (returns) water-use categories are not shown in figure 5 or defined in this section because data were not compiled or included in Maupin and others (2014).

Aquaculture.-Water use associated with the farming of organisms that live in water (such as finfish and shellfish) and offstream water use associated with fish hatcheries.

Domestic.-Water used for indoor household purposes such as drinking, food preparation, bathing, washing clothes and dishes, and flushing toilets and for outdoor purposes such as watering lawns and gardens. Domestic water use includes water provided to households by a public water supply (domestic deliveries from public suppliers) and self-supplied water.

Industrial.-Water used for fabrication, processing, washing, and cooling. Includes industries such as chemical and allied products, food, mining, paper and allied products, petroleum refining, and steel.

Irrigation.-Water that is applied by an irrigation system to assist crop and pasture growth or to maintain vegetation on recreational lands such as parks and golf courses. Irrigation includes water that is applied for preirrigation, frost protection, chemical application, weed control, field preparation, crop cooling, harvesting, dust suppression, leaching of salts from the root zone, and conveyance losses.
Livestock.-Water used for livestock watering, feedlots, dairy operations, and other on-farm needs. Types of livestock include dairy cows and heifers, beef cattle and calves, sheep and lambs, goats, hogs and pigs, horses and poultry.

Mining.-Water used for the extraction of naturally occurring minerals including solids (such as coal, sand, gravel, and other ores), liquids (such as crude petroleum), and gases (such as natural gas). Also includes uses associated with quarrying, milling of mined materials, injection of water for secondary oil recovery or for unconventional oil and gas recovery (such as hydraulic fracturing), and other operations associated with mining activity. Does not include water associated with dewatering of the aquifer that is not put to beneficial use. Also does not include water used in processing, such as smelting, refining petroleum, or slurry pipeline operations. These processing uses are considered industrial water use.

Public supply.-Water supplied from a public supplier and used for such purposes as firefighting, street washing, flushing of water lines, and maintaining municipal parks and swimming pools. Generally, public-use water is not billed by the public supplier.

Thermoelectric.-Water used in the process of generating electricity with steam-driven turbine generators.
For more information about this publication, contact

Director, USGS Dakota Water Science Center, South Dakota Office 1608 Mountain View Road

Rapid City, SD 57702

(605) 394-3200

For additional information visit https://sd.water.usgs.gov

Publishing support provided by the

Rolla Publishing Service Center 
Back Cover. Top photo: Temporary crew camps, such as this one near Medora, North Dakota, represent one of many indirect uses of water that increase in areas of unconventional oil and gas development.

Middle photo: Water truck in background is providing maintenance water to a producing well drilled in the Bakken Formation near Williston, N. Dak.

Bottom photo: Water depots, such as this one near Watford, N. Dak., use freshwater from groundwater and surface water to fill water trucks to supply water for unconventional oil and gas development. 


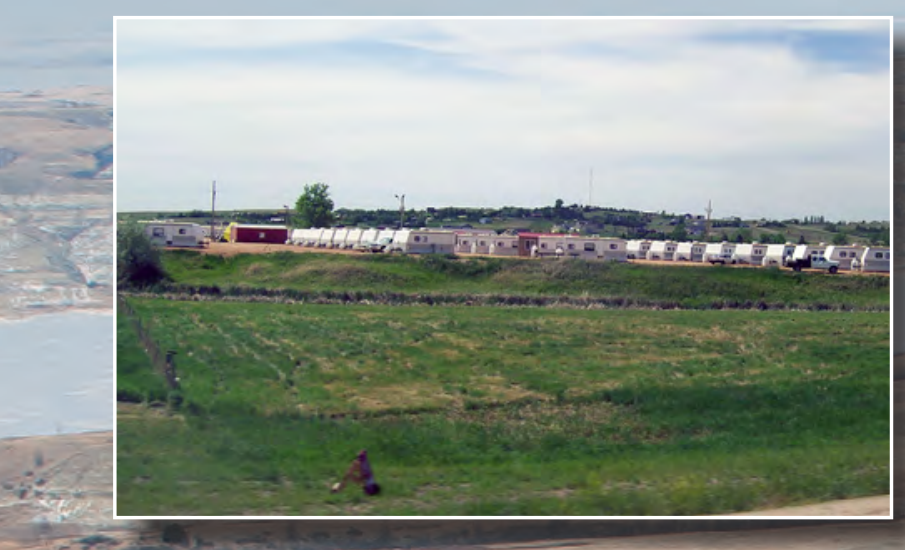

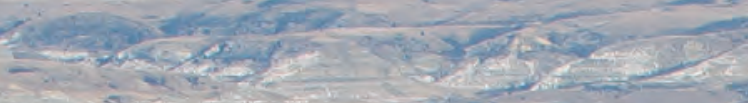

$\frac{\pi}{2}$

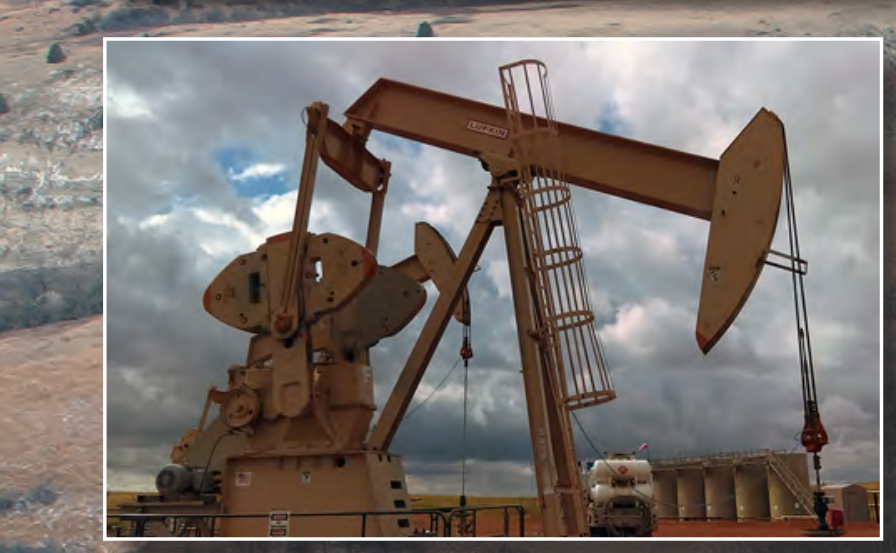

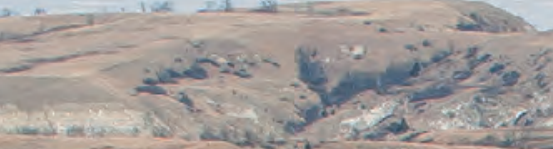
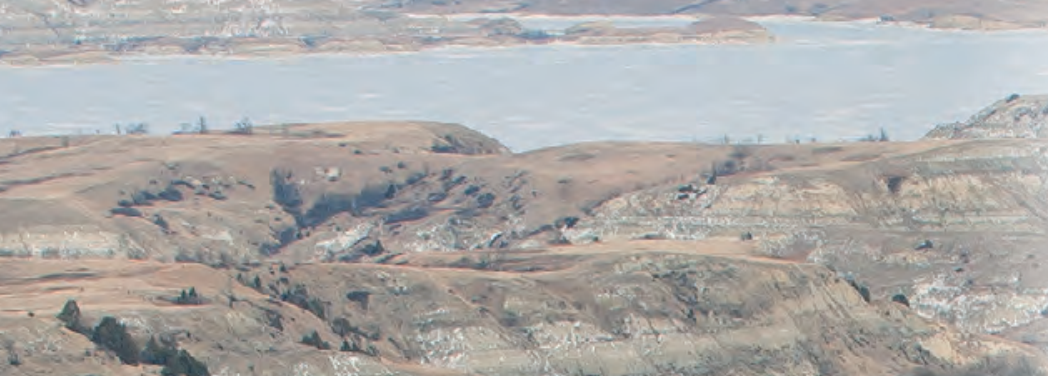

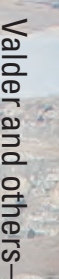

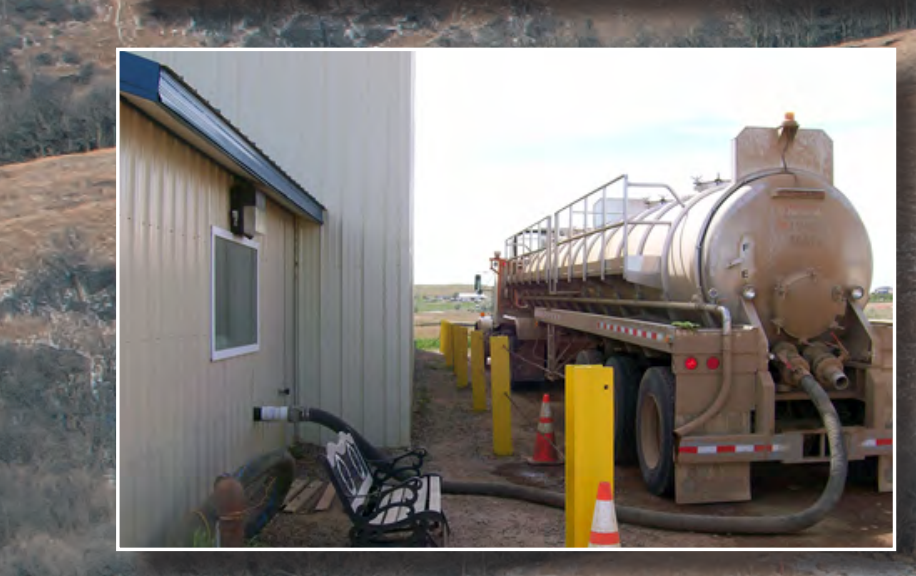

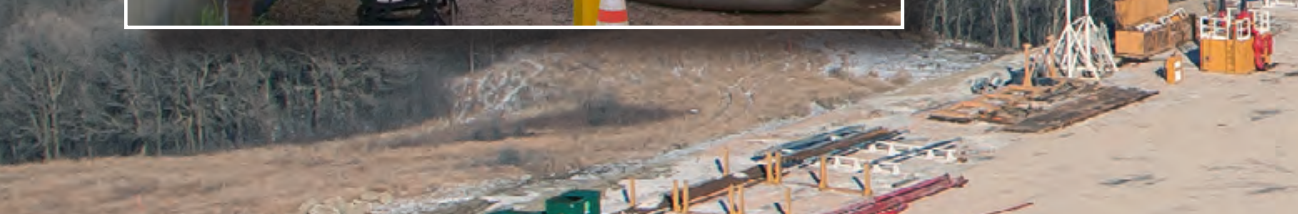

W 1 - in

trindinces
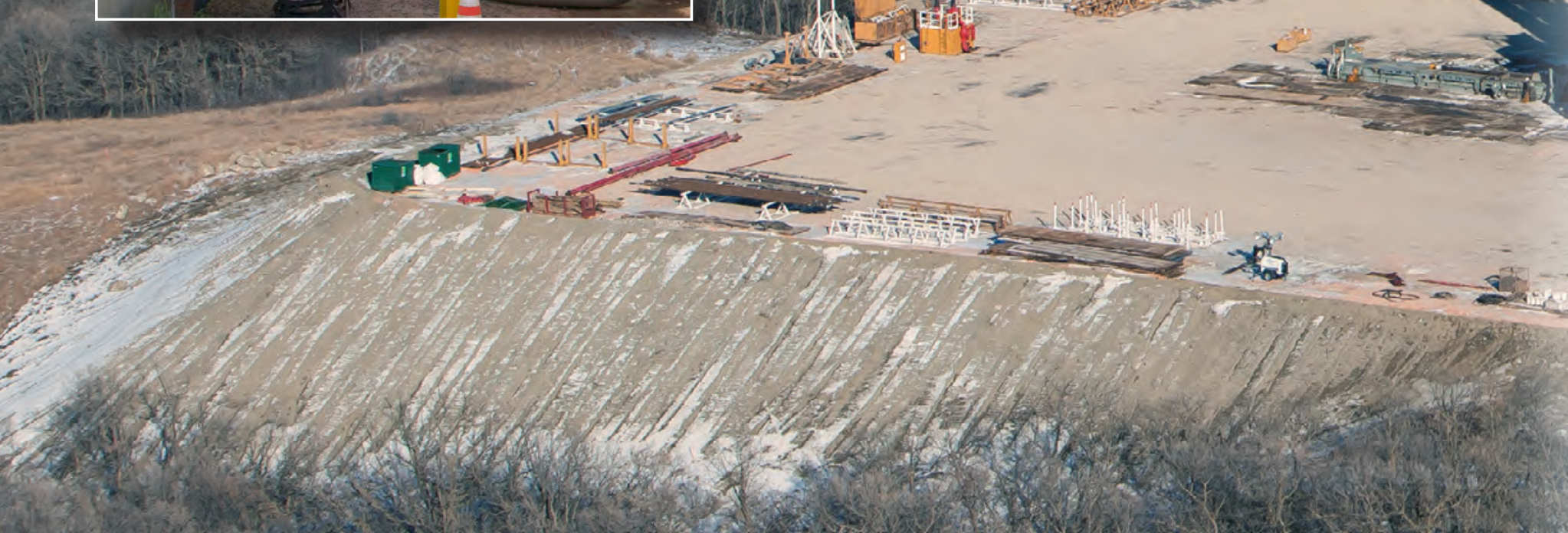

(3)

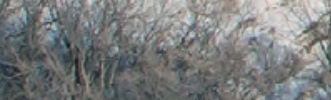

(1) $2 x^{2}$

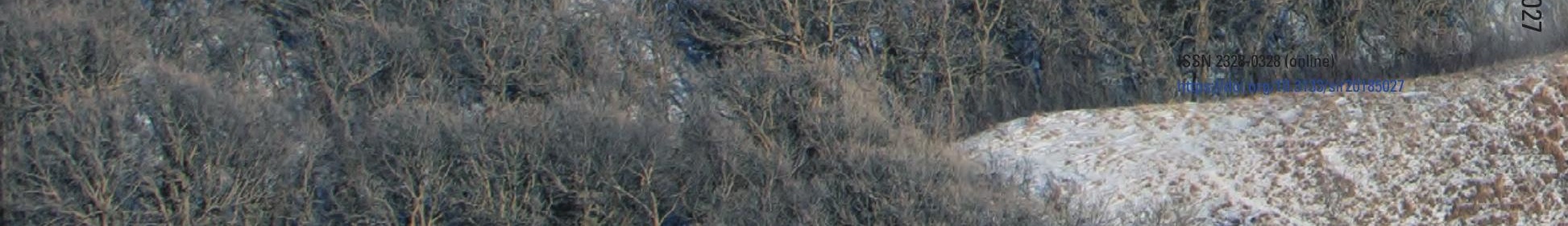

